\title{
Identification of a stereotypic molecular arrangement of endogenous glycine receptors at spinal cord synapses
}

\author{
Stephanie A Maynard ${ }^{1}$, Philippe Rostaing ${ }^{1}$, Natascha Schaefer ${ }^{2}$, Olivier Gemin ${ }^{1}$, Adrien \\ Candat $^{1}$, Andréa Dumoulin ${ }^{1}$, Carmen Villmann ${ }^{2}$, Antoine Triller $^{1 *}$, Christian G \\ Specht $^{1,3} *$
}

${ }^{1}$ Institut de Biologie de l'ENS (IBENS), Ecole Normale Supérieure, CNRS, Inserm, Université PSL, Paris, France

${ }^{2}$ Institute for Clinical Neurobiology, University Hospital, Julius-Maximilians-University, Würzburg, Germany

${ }^{3}$ Diseases and Hormones of the Nervous System (DHNS), Inserm, Université Paris-Saclay, Le Kremlin-Bicêtre, Paris, France

* correspondence: christian.specht@inserm.fr, triller@biologie.ens.fr 6

ORCID numbers:

8 Stephanie A Maynard 0000-0002-7838-3676

Natascha Schaefer 0000-0001-9743-1963

Olivier Gemin 0000-0003-3210-7876

Andréa Dumoulin 0000-0003-1309-3448

Carmen Villmann 0000-0003-1498-6950

3 Antoine Triller 0000-0002-7530-1233

Christian G Specht 0000-0001-6038-7735

Short title:

Quantitative SR-CLEM of glycinergic synapses

\section{$\underline{\text { Key words }}$}

single molecule localization microscopy (SMLM); glycine receptor (GlyR); gephyrin;

1 photoactivated localization microscopy (PALM); correlative light and electron microscopy

32 (CLEM); super-resolution CLEM (SR-CLEM); super-resolution radial fluctuation (SRRF)

33 analysis; spinal cord; synapse; hyperekplexia; oscillator mouse model; hypomorph 
bioRxiv preprint doi: https://doi.org/10.1101/2021.09.09.459599; this version posted September 13, 2021. The copyright holder for this preprint (which was not certified by peer review) is the author/funder, who has granted bioRxiv a license to display the preprint in perpetuity. It is made available under aCC-BY-NC 4.0 International license.

\section{Abstract}

Precise quantitative information about the molecular architecture of synapses is essential to understanding the functional specificity and downstream signaling processes at specific populations of synapses. Glycine receptors (GlyRs) are the primary fast inhibitory neurotransmitter receptors in the spinal cord and brainstem. These inhibitory glycinergic networks crucially regulate motor and sensory processes. Thus far the nanoscale organization of GlyRs underlying the different network specificities has not been defined. Here, we have quantitatively characterized the molecular arrangement and ultra-structure of glycinergic synapses in spinal cord tissue using quantitative super-resolution correlative light and electron microscopy (SR-CLEM). We show that endogenous GlyRs exhibit equal receptor-scaffold occupancy and constant packing densities of about 2000 GlyRs $\mu \mathrm{m}^{-2}$ at synapses across the spinal cord and throughout adulthood, even though ventral horn synapses have twice the total copy numbers, larger postsynaptic domains and more convoluted morphologies than dorsal horn synapses. We demonstrate that this stereotypic molecular arrangement is maintained at glycinergic synapses in the oscillator mouse model of the neuromotor disease hyperekplexia despite a decrease in synapse size, indicating that the molecular organization of GlyRs is preserved in this hypomorph. We thus conclude that the morphology and size of inhibitory postsynaptic specializations rather than differences in GlyR packing determine the postsynaptic strength of glycinergic neurotransmission in motor and sensory spinal cord networks.

\section{Introduction}

Synaptic transmission relies on the integration of spatially and temporally controlled signals by neurotransmitter receptors in the postsynaptic membrane. The molecular arrangement of postsynaptic receptors and scaffold proteins is therefore key to the synaptic function, however the heterogeneity and complexity of postsynaptic sites has made it difficult to resolve its internal organization, to ascertain whether distinct compositional states exist, and to determine how the organization is affected in disease.

Glycine receptors (GlyRs) are the main inhibitory neurotransmitter receptors in the adult spinal cord and brainstem. Glycinergic neurons arise from different embryonic origins, with specific types of neurons residing in characteristic layers of the spinal cord (Lu et al., 2015). Depending on their location, glycinergic neurons mediate sensory and motor information in the dorsal and ventral spinal cord, respectively, which requires high reliability and fidelity of 
bioRxiv preprint doi: https://doi.org/10.1101/2021.09.09.459599; this version posted September 13, 2021. The copyright holder for this preprint (which was not certified by peer review) is the author/funder, who has granted bioRxiv a license to display the preprint in perpetuity. It is made available under aCC-BY-NC 4.0 International license.

transmission (Alvarez, 2017). Consequently, deficits in glycinergic transmission are involved in pain mechanisms (Harvey et al., 2004) and motor-related neurological diseases (Schaefer et al., 2018). The electrophysiological properties of glycinergic currents indicate that only a limited number of receptors are activated by the release of a single synaptic vesicle (Oleskevich et al., 1999, Singer \& Berger, 1999), suggesting that the nanoscale organization of the receptors determines signal amplitude.

It has been shown that neurotransmitter receptors at excitatory and inhibitory synapses are organized within sub-synaptic domains (SSDs) that are aligned with presynaptic elements of the active zone (AZ) (Crosby et al., 2019, MacGillavry et al., 2013, Pennacchietti et al., 2017, Tang et al., 2016, Yang et al., 2021). These so-called trans-synaptic nanocolumns are thought to increase the efficacy of synaptic transmission (Haas et al., 2018). At mixed inhibitory synapses, both glycine and $\mathrm{GABA}_{\mathrm{A}}$ receptors are immobilized opposite to presynaptic release sites through direct interactions with their common scaffold protein gephyrin (Maric et al., 2011, Specht et al., 2013, Yang et al., 2021). However, accurate quantification of receptor numbers and their precise arrangement within postsynaptic sites in native tissue is lacking. Further, the question is raised as to whether the structure of glycinergic synapses varies in functionally diverse circuits of the dorsal and ventral spinal cord, if it changes over time, and if it is disturbed in GlyR pathologies such as the neuromotor disease hyperekplexia in humans. In hyperekplexic patients, mutations in the receptor subunit genes GLRAI and GLRB lead to decreased receptor availability and disturbances in glycinergic transmission, resulting in exaggerated startle reflexes, muscle hypertonia and stiffness in infancy (Chung et al., 2013, Chung et al., 2010, Schaefer et al., 2013).

To investigate whether the molecular arrangement of GlyRs may account for differences in the functional specificity of sensory and motor circuits we have quantitatively analyzed the ultra-structural organization of inhibitory synapses in spinal cord tissue. We have combined molecule counting of endogenous GlyRs using single molecule localization microscopy (SMLM) with correlative light and electron microscopic analysis (CLEM) to obtain receptor numbers as well as detailed spatial information of the synapse at the nanometer scale. We have further examined to what extent the molecular organization is maintained throughout adult development and during GlyR $\alpha 1$-deficiency. We show that GlyRs are packed at a constant density of about 2000 receptor complexes per $\mu \mathrm{m}^{2}$ at mature synapses, suggesting that they are assembled in a stereotypic fashion. This GlyR molecular organization is 
102 maintained in the hyperekplexia model oscillator despite a decrease in ventral synapse size,

103

104

105

106

107

108

109

110 indicating that GlyR $\alpha 1$-deficiency does not affect the integrity of the synaptic arrangement as such. Collectively, our results provide the structural basis for understanding the mechanisms underlying receptor availability and the integration of neurotransmitter-induced signals.

\section{$\underline{\text { Results }}$}

\section{Generation of a KI model expressing endogenous levels of mEos4b-GlyR}

In order to quantify GlyR numbers and their precise distribution at synapses we generated a knock-in (KI) mouse model expressing endogenous mEos4b-tagged GlyR $\beta$ subunits (Fig. S1). The $\beta$-subunit drives the synaptic localization of the receptor through direct interactions with the synaptic scaffold protein gephyrin at inhibitory synapses (Kim et al., 2006, Meyer et al., 1995). To date, labeling of GlyR $\beta$ in situ using immunocytochemistry has proven difficult due to a lack of reliable antibodies that recognize the native $\beta$-subunit (only antibodies for Western blotting recognizing the denatured protein are available), which has severely limited the study of the receptor. The coding sequence of mEos $4 \mathrm{~b}$ was inserted in exon 2 of the Glrb gene by homologous recombination supported by a guide RNA (CRISPR-Cas9) to increase recombination efficiency (ICS, Illkirch, France). Specifically, the fluorophore sequence was inserted after the signal peptide and before the N-terminus of the mature GlyR $\beta$ subunit, meaning that it does not interrupt the coding sequence of the receptor (Fig. S1B). The correct insertion was confirmed by amplification and sequencing of genomic DNA. Semi-quantitative RT-PCR revealed that equal concentrations of $G l r b^{\text {Eos }}$ and the wild-type transcript $\left(G l r b^{\text {WT }}\right)$ are expressed in heterozygous animals. When bred to homozygosity, KI animals follow Mendelian inheritance (Fig. S2A), exhibit normal lifespans (Fig. S2B), and display no overt phenotype, suggesting that the GlyR expression and/or function are not altered.

To further confirm that GlyR function is not altered by the introduction of mEos $4 \mathrm{~b}$, we carried out whole cell recordings in cultured spinal cord neurons of Glrb $b^{\text {WT/WT }}$ and homozygous Glrb ${ }^{\text {Eos/Eos }}$ animals (Fig. S2C). The agonist glycine was applied in a concentration series from $1 \mu \mathrm{M}$ to $300 \mu \mathrm{M}$. The maximal chloride currents at saturating glycine concentrations of $300 \mu \mathrm{M}$ were not significantly different in Glrb ${ }^{\text {Eos/Eos }}$ animals, despite a minor increase in the $\mathrm{EC}_{50}\left(G l r b^{\mathrm{WT} / \mathrm{WT}} 100 \pm 5 \mu \mathrm{M}, G l r b^{\mathrm{Eos} / \mathrm{Eos}} 130 \pm 9 \mu \mathrm{M}, \mathrm{p}=\right.$ $0.0123 \mathrm{t}$-test). In view of the millimolar concentration of glycine present during synaptic transmission (Beato, 2008, Legendre, 1998) these data indicate that the presence of the $\mathrm{N}$ - 
135 terminal fluorophore does not affect GlyR function under physiological conditions. Hill 136 coefficients for Glrb ${ }^{\mathrm{WT} / \mathrm{WT}}$ and $G l r b^{\mathrm{Eos} / \mathrm{Eos}}$ were in a range of 3.5-4, arguing for cooperativity

137 of the subunits during glycine binding. The glycinergic origin of the chloride influx was

138 confirmed by blocking the currents recorded in the presence of $100 \mu \mathrm{M}$ glycine with $10 \mu \mathrm{M}$

139 strychnine.

141 Quantitative confocal imaging of endogenous mEos4b-GlyRß and mRFP-gephyrin at 142 spinal cord synapses in tissue

143 To verify the expression and synaptic targeting of the mEos4b-GlyR $\beta$ protein we carried out

144 quantitative confocal imaging in $40 \mu \mathrm{m}$ vibratome tissue sections. Glrb ${ }^{\text {Eos/Eos }}$ animals were

145 crossed with a previously established KI mouse line expressing mRFP-tagged gephyrin to

146 visualize inhibitory postsynaptic sites (Specht et al., 2013). Since the synaptic localization of

147 the GlyR is strictly dependent on its interaction with gephyrin (Patrizio et al., 2017), we

148 expected a high degree of co-localization of the two proteins in the brainstem and spinal cord

149 (Zeilhofer et al., 2005). Indeed, mEos4b-GlyR $\beta$ was widely expressed at inhibitory synapses

150 in the thalamus, midbrain, pons and medulla (Fig. S3). Very little fluorescence was detected

151 in the forebrain despite the high reported expression of the Glrb transcript (Fujita et al., 1991,

152 Malosio et al., 1991), suggesting that protein levels are controlled by post-transcriptional

153 mechanisms in a region-specific manner, as previously proposed (Weltzien et al., 2012).

154

155 In the spinal cord, we observed bright punctate mEos $4 b-G l y R \beta$ signals throughout the gray

156 matter, with the exception of the superficial laminae of the dorsal horn, where the intensity of

157 the green fluorescence was markedly lower (Fig. 1A). The expression of mEos4b-GlyR $\beta$ and

158 mRFP-gephyrin in homozygous and heterozygous animals was quantified in confocal images

159 of thoracic and lumbar spinal cord slices at 2 months (Fig. 1B) and 10 months of age (Fig. S4).

160 The same region of the ventral horn, indicated by the white square in Fig. 1A was taken for

161 quantification of mEos4b-GlyR $\beta$ and mRFP-gephyrin expression in all conditions. The

162 integrated mEos $4 \mathrm{~b}$ intensity at gephyrin-positive ventral horn synapses was exactly two times

163 higher in $G l r b^{\text {Eos/Eos }}$ mice than in $G l r b^{\text {Eos/WT }}$, demonstrating that both alleles are expressed

164 with the same efficiency, and that the mEos4b fluorophore does not affect the synaptic

165 localization of the receptor complexes. To confirm that the confocal image acquisition was in

166 the linear dynamic range we bleached the mEos $4 \mathrm{~b}$ fluorophores by repeatedly scanning the 
bioRxiv preprint doi: https://doi.org/10.1101/2021.09.09.459599; this version posted September 13, 2021. The copyright holder for this preprint (which was not certified by peer review) is the author/funder, who has granted bioRxiv a license to display the preprint in perpetuity. It is made available under aCC-BY-NC 4.0 International license.

same tissue area at constant laser power (Fig. 1A, white square), which resulted in a linear decay of pixel intensities over a range of more than 20 fold (Fig. 1C).

Across the spinal cord slices, the intensity of synaptic mEos4b-GlyR $\beta$ puncta increased from dorsal to ventral both in homozygous (Fig. 1D-E) and in heterozygous animals (Fig. S4). Similarly, mRFP-gephyrin fluorescence was higher and more variable in the ventral horn, suggesting that synapses were on average about twice as big as those in the dorsal horn, despite being fewer in number (Fig. $1 \mathrm{~F}, \mathrm{~S} 4)$. The $\mathrm{mEos} 4 \mathrm{~b} / \mathrm{mRFP}$ ratio was relatively equal across the spinal cord with the exception of the superficial layers of the dorsal horn, where GlyR levels were largely exceeded by gephyrin (Fig. 1A and D). The lower GlyR-scaffold occupancy of synapses in laminae I-III can be explained by the predominant expression of $\mathrm{GABA}_{\mathrm{A}} \mathrm{Rs}$ that compete for receptor binding sites at these mixed inhibitory synapses (Alvarez et al., 1996, Lorenzo et al., 2014, Todd et al., 1996).

\section{Dual-color super-resolution imaging of glycinergic spinal cord synapses}

To quantify the observed structural differences at super-resolution, we combined radial fluctuation (SRRF) analysis of mRFP-gephyrin and photo-activated localization microscopy (PALM, a form of SMLM) of mEos $4 b-G l y R \beta$ in spinal cord tissue from double KI animals. Sucrose impregnated cryosections of $2 \mu \mathrm{m}$ thickness were prepared from dorsal and ventral tissue and placed on gridded coverslips (Fig. 2A). SRRF and PALM images were acquired sequentially. First, mRFP signals were recorded with high intensity $561 \mathrm{~nm}$ laser illumination until all mRFP fluorophores were bleached (10,000 frames). mEos4b was then photoconverted with increasing $405 \mathrm{~nm}$ laser intensity and imaged at $561 \mathrm{~nm}$ for 25,000 frames until all available fluorophores were exhausted. By acquiring both fluorophores, mRFP and photoconverted mEos $4 \mathrm{~b}$, in the same emission band $(607 / 36 \mathrm{~nm})$, any chromatic misalignment between the two super-resolved images was eliminated. SRRF reconstruction was carried out on the raw mRFP image sequence and PALM images were generated from individual mEos4b detections using Gaussian peak fitting (Fig. 2B). The spatial resolution was estimated using Fourier ring correlation (FRC), which measures the similarity of two images as a function of spatial frequency by comparing the odd and even frames of the raw image sequence. According to this analysis, the spatial resolution of SRRF was $46 \mathrm{~nm}$ and that of PALM $21 \mathrm{~nm}$. It should be noted that the synaptic puncta in the SRRF images appear somewhat smaller and brighter due to differences in the reconstruction methods that result in differences in the dynamic intensity range. 
bioRxiv preprint doi: https://doi.org/10.1101/2021.09.09.459599; this version posted September 13, 2021. The copyright holder for this preprint (which was not certified by peer review) is the author/funder, who has granted bioRxiv a license to display the preprint in perpetuity. It is made available under aCC-BY-NC 4.0 International license.

202 The majority of synaptic clusters in the dual super-resolution images were small and spherical or elongated. Larger clusters displayed a variety of morphologies including elongated shapes seen in side-view (Fig. 2B) as well as convoluted structures, and were more frequently observed in the ventral horn (Fig. S5). All mEos4b-GlyR clusters closely matched the mRFPgephyrin clusters, confirming the localization of the receptors in the postsynaptic membrane. As expected of two directly interacting synaptic components the degree of co-localization of mEos4b-GlyR $\beta$ and mRFP-gephyrin was very high, with mean intensity correlation quotients (ICQ) around 0.3 (Fig. 2C and S5), a value indicative of close spatial correlation ( $\mathrm{Li}$ et al., 2004). Minor mismatches between the super-resolution images are explained by the fact that the majority of synapses are seen in cross-section and that the two fluorophores are located on opposite sides of the postsynaptic membrane ( 30 nm distance, (Specht et al., 2013)). There were no obvious differences between the ICQ values of dorsal versus ventral synapses $(0.28$ -

214 0.3), indicating equivalent GlyR $\beta$-gephyrin binding in the two regions. It should be noted that

215 the ICQ reflects relative fluctuations between images and is not sensitive to absolute

216 differences in signal intensities, resulting in similar ICQ values in animals that are

217 heterozygous or homozygous for mRFP-gephyrin (Fig. 2C). Quantitative comparison of

218 mEos $4 b-G l y R \beta$ and mRFP-gephyrin intensities confirmed that the amounts of receptor and scaffold proteins are closely correlated, and that the occupancy of receptor binding sites is the same in the dorsal and ventral horn, independent of synapse size (Fig. 2D and S5). To estimate the sizes of the synapses we applied a density threshold to the PALM pointillist images and calculated the areas of the mEos4b-GlyR $\beta$ clusters (Fig. 2E). The mean synapse area in the ventral horn was larger and more variable than in the dorsal region, both in animals of 2 and 10 months of age (Fig. 2F). We also remarked that the overall number of synapses in ventral horn tissue was lower compared to the dorsal horn, significantly so by 10 months (Fig. $2 \mathrm{G}$, see also Fig. 1F and S4). The inverse relationship between synapse number and size is likely due to the presence of different cell types in the two regions, specifically Renshaw cells and large motor neurons in the ventral horn that require strong inhibitory control (e.g.

229 (Bhumbra et al., 2014)).

\section{Quantification of GlyR numbers and densities at native spinal cord synapses}


count the number of GlyRs at spinal cord synapses. The total number of mEos $4 b-G l y R \beta$ detections at synapses (Fig. S6) were converted into molecule numbers taking into account the blinking properties of the fluorophore and the $\alpha_{3}: \beta_{2}$ stoichiometry of the pentameric GlyR complex (Durisic et al., 2014, Patrizio et al., 2017). To this aim, the average number of detections per fluorophore (detections/burst) and the fraction of functional fluorophores (probability of detection, $\mathrm{P}_{\text {det }}$; Fig. S7) were determined in each set of experiments using extrasynaptic receptor complexes (Fig. 2E, red arrowheads). We calculated a median copy number of 114 pentameric GlyR complexes at dorsal horn synapses and twice that number at ventral horn synapses in 2 month old animals (Fig. 2H). Copy numbers were almost identical at 10 months (Fig. S8), indicating that the glycinergic network was mature at both time points. These numbers exceed estimates derived from electrophysiological recordings in new-born, juvenile and adult rat spinal cord neurons that suggest the activation of as few as 7 and up to about 110 GlyRs during an average miniature inhibitory postsynaptic current (mIPSC) (Chery $\&$ de Koninck, 1999, Oleskevich et al., 1999, Singer \& Berger, 1999, Takahashi, 1992). The high numbers of GlyRs measured by fluorophore counting therefore imply that the available receptors are not saturated by quantal release, which is likely to increase the dynamic range of postsynaptic inhibition (Alvarez, 2017).

Our quantitative PALM data further demonstrate that differences in receptor numbers result from differences in synapse size (Fig. 2F). By combining the two parameters, we derived mean GlyR densities of $\sim 2000 \mu \mathrm{m}^{-2}$ (Fig. 2I, S8). Similar receptor densities of $1250 \mu \mathrm{m}^{-2}$ and $\sim 2000 \mu \mathrm{m}^{-2}$ have been measured at GABAergic synapses in cerebellar stellate cells and in cultured hippocampal neurons, respectively (Liu et al., 2020, Nusser et al., 1997). We saw no differences in the GlyR packing density at dorsal and ventral horn synapses, nor did we find a clear size dependence, as determined by linear regression of all synapses (Fig. 2I) and the evolution of the coefficient of variation of GlyR density with respect to synapse area (Fig. S8). These findings are significant because they indicate that GlyR density is constant and largely independent of neuron type, embryonic origin or physiological function. Assuming that gephyrin molecules are clustered at densities of up to $9000 \mu \mathrm{m}^{-2}$ (Specht et al., 2013), our data also suggest that close to $50 \%$ of the receptor binding sites are occupied by GlyRs at native spinal cord synapses, in line with earlier observations of GlyR subunits that were overexpressed in cultured neurons (Patrizio et al., 2017). 
bioRxiv preprint doi: https://doi.org/10.1101/2021.09.09.459599; this version posted September 13, 2021. The copyright holder for this preprint (which was not certified by peer review) is the author/funder, who has granted bioRxiv a license to display the preprint in perpetuity. It is made available under aCC-BY-NC 4.0 International license.

\section{Quantitative SR-CLEM of GlyRß molecular organization}

To integrate the results of molecule counting with three-dimensional ultra-structural information and the exact synapse size, we further analyzed dorsal and ventral horn synapses by SR-CLEM. Previously imaged cryosections of Glrb $b^{\text {Eos/Eos }}$ tissue from 10 month old animals were embedded in epoxy resin, and ultra-thin $(70 \mathrm{~nm})$ serial sections were collected on EM slot grids with an ultramicrotome (Fig. 3A). After osmium tetroxide enhancement, electron micrographs of identified synapses were acquired in all serial sections and registered manually, using the coverslip grids and cellular structures as reference (Fig. 3B-C). All of the synapses that were both, imaged by PALM and reconstructed with EM were functionally mature, as judged by the apposition of a single presynaptic terminal containing synaptic vesicles. In line with our PALM data we found that glycinergic synapses in the ventral horn were substantially larger and more variable in size than those in the dorsal horn (Fig. 3C-D). There was good correspondence between the calculated synapse areas in the EM and PALM image reconstructions, even though PALM underestimated the sizes of some large ventral horn synapses (Fig. S9). This is probably due to the fact that a majority of synapses are tilted, and that the axial component of the area is not captured in the SMLM projections. Whereas most synapses in the dorsal horn were macular, ventral synapses were frequently composed of sub-domains (Fig. 3E-G). In agreement with earlier studies (Alvarez et al., 1997, Lushnikova et al., 2011, Santuy et al., 2018), the degree of complexity scales with the size of the postsynaptic specialization (Fig. 3F), and was taken into account for the calculation of the combined area in the EM serial sections.

The ratio of GlyR copy numbers and the area of the inhibitory postsynaptic specialization obtained by EM resulted in average receptor densities of approximately $2000 \mu \mathrm{m}^{-2}$ (Fig. 3H). Consistent with our PALM estimates we did not observe significant differences between synapses in the dorsal and the ventral horn (Fig. 2I, S8). Furthermore, the GlyR packing density was not dependent on synapse size (Fig. 3I), supporting an earlier proposal (Lim et al., 1999). This suggests that GlyRs are assembled in a systematic manner, where receptor numbers increase linearly with synapse size. Since the morphological complexity of synapses increases with size, it can also be concluded that GlyR occupancy at individual sub-domains of the postsynaptic sites is uniform. GlyR densities were indeed not significantly different within sub-clusters of reconstructed synapses (Fig. 3G and I, black data points). Together, these findings point to a tight regulation of the architecture of glycinergic synapses across different molecular length scales, where GlyRs are arranged in sub-synaptic signaling units. 


\section{GlyR packing density is unaltered in the hyperekplexia mouse model oscillator}

Having identified that GlyRs have a stereotypic molecular organization that is maintained throughout adulthood and across synapses in different neuronal circuits, we questioned whether this arrangement is altered in a mouse model of hyperekplexia, a motor-related neurological disease that significantly impacts motor processing in the ventral horn of the spinal cord. The mouse mutation oscillator $\left(G l r a l^{\text {spd-ot/spd-ot }}\right)$ is recessively inherited and causes a microdeletion and frameshift in the TM3-4 intracellular loop of the GlyR $\alpha 1$ subunit leading to subunit truncation and subsequent loss of functional GlyRs at synapses (Kling et al., 1997). Homozygous oscillator mice do not live past 3 weeks of age (Buckwalter et al., 1994). In contrast, heterozygous animals have a normal lifespan and exhibit a more subtle phenotype. Glral ${ }^{\text {spd-ot/WT }}$ mice display an increased startle reflex and lower GlyR $\alpha 1$ levels (Kling et al., 1997), making them a suitable model for human hyperekplexia. We generated mutant mice that were homozygous for mEos4b-GlyR $\beta$ (as described above) and

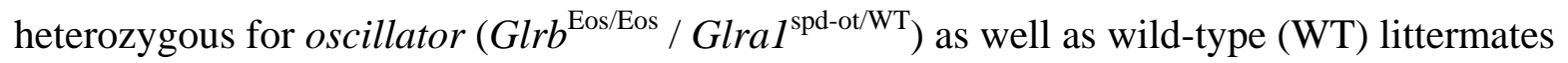

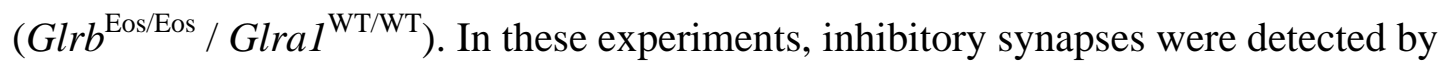
immunolabeling of endogenous gephyrin using the mAb7a antibody.

Quantitative confocal imaging in $40 \mu \mathrm{m}$ vibratome tissue sections showed bright punctate mEos4b-GlyR $\beta$ signals localized at synapses (Fig.4A). Across the spinal cord slices, the intensity of synaptic mEos $4 b-G l y R \beta$ puncta increased from dorsal to ventral in wild-type animals (Fig. 4B), replicating the intensity profile observed previously (Fig. 1D). The intensity of synaptic mEos4b-GlyR $\beta$ puncta in heterozygous oscillator animals were substantially lower than those of WT littermates, which explains the reductions in membrane levels of GlyR and gephyrin previously observed by Western blotting (Kling et al., 1997). The mEos4b/gephyrin-7a ratio was relatively equal across the spinal cord with greater variation seen in oscillator. No ectopic GlyR $\beta$ clusters were detected, meaning that GlyRs and gephyrin always colocalized (Fig. S10). The number of gephyrin-positive synapses across the spinal cord remained unchanged between WT and oscillator. synapses in tissue slices of dorsal and ventral spinal cord, as well as the mEos $4 \mathrm{~b}$ detection density (Fig S11), in order to understand the alterations in glycinergic synapse architecture in 
bioRxiv preprint doi: https://doi.org/10.1101/2021.09.09.459599; this version posted September 13, 2021. The copyright holder for this preprint (which was not certified by peer review) is the author/funder, who has granted bioRxiv a license to display the preprint in perpetuity. It is made available under aCC-BY-NC 4.0 International license.

this mutant mouse model. The detections per synapse were converted into molecule numbers as described before (Fig. S7 and S12). In WT animals we observed small and spherical dorsal synapses and larger, elongated ventral synapses, while oscillator synapses appeared small both in dorsal and ventral horn tissue (Fig. 5A). This was confirmed by quantitative analysis. The mean synapse area in the ventral horn was significantly larger than in the dorsal region in WT animals (Fig. 5B), in agreement with our earlier data (Fig. 2F). However, this difference was lost in Glral $1^{\text {spd-ot/WT }}$ littermates. The overall number of synapses was lower in ventral horn tissue compared to the dorsal horn in both WT and oscillator animals (Fig. 5C). These data suggest that the decrease in functional receptors in heterozygous oscillator mice manifests itself as a reduction in the size of ventral synapses.

We further quantified the total number of endogenous GlyRs at synapses (Fig. 5D) and found that the number and distribution of receptors in WT mice matched that of 2 and 10 month old WT animals analyzed previously (Fig. 2H and S8). This is remarkable considering that these experiments were performed independently and subsequent to the previous dataset, attesting to the stability of the measurements. It should also be pointed out that the GlyR copy numbers were indistinguishable from those in mRFP-gephyrin double KI animals, confirming that the presence of the fluorophores does not affect their expression and synaptic clustering. We found similar copy numbers in dorsal synapses of heterozygous oscillator mice compared to WT littermates, however in ventral tissue we found a shift towards lower receptor numbers per synapse, suggestive of smaller synapses. By combining the measurements of GlyR copy numbers with synapse area we could derive the receptor density. Consistent with our previous PALM data, we found a constant receptor density independent of synapse size in WT mice, as judged by the shallow slope of the linear regression (Fig. 5E). We observed a similar and constant GlyR packing density in synapses of oscillator mice. This suggests that despite a decrease in the total number of functional GlyRs in the heterozygous oscillator mouse model the molecular organization underlying receptor clustering within the synapse is maintained, in line with the lack of an overt neuromotor phenotype in these animals. In other words, the receptors are assembled stereotypically in the disease model, as in WT, with synapse size consistently scaling with receptor number. Together, our findings describe a highly regulated architecture of glycinergic synapses in both wild-type animals as well as in a model of synaptic pathology, providing a structural basis of glycinergic signaling. 
bioRxiv preprint doi: https://doi.org/10.1101/2021.09.09.459599; this version posted September 13, 2021. The copyright holder for this preprint (which was not certified by peer review) is the author/funder, who has granted bioRxiv a license to display the preprint in perpetuity. It is made available under aCC-BY-NC 4.0 International license.

\section{Discussion}

Combining single molecule PALM imaging, molecular counting and 3D electron microscopy we have shown that glycinergic synapses in different regions of the spinal cord follow the same structural principle, insofar as their receptor-scaffold occupancy and packing densities are the same. This uniformity extends to the sub-synaptic level. The presence of so-called sub-synaptic domains (SSDs) at inhibitory synapses has been shown by super-resolution microscopy (Crosby et al., 2019, Dzyubenko et al., 2016, Pennacchietti et al., 2017, Specht et al., 2013, Yang et al., 2021). However, it remains controversial whether the identified patterns represent the overall structure of the postsynaptic specialization itself or whether they reflect intra-synaptic variations in molecule clustering. Our quantitative SR-CLEM data lend support to the first model, whereby inhibitory postsynaptic sites in the spinal cord are composed of sub-domains that determine the distribution of the GlyRs. This organization is achieved through direct interactions between GlyRs and gephyrin, as shown by the close correspondence between the receptors and scaffold proteins. As such, the GlyR sub-clusters at spinal cord synapses do not constitute SSDs within the postsynaptic membrane in the strict sense, since they exhibit uniform binding to the synaptic scaffold (discussed in (Yang \& Specht, 2019)). The stereotypic GlyR density within SSDs observed in our study supports the idea that these structures can instead be equated with the convolutions of the synaptic junction observed by EM (Alvarez et al., 1997, Lushnikova et al., 2011, Peters \& Palay, 1996, Santuy et al., 2018). The formation of these convolutions is probably a consequence of gephyrin oligomerization that appears to introduce an asymmetry in the synaptic scaffold. The situation may be different at GABAergic synapses, where the co-existence of gephyrin-dependent and gephyrin-independent clustering mechanisms could lead to the formation of spatially more restricted SSDs containing different $\mathrm{GABA}_{\mathrm{A}} \mathrm{R}$ subtypes (Pennacchietti et al., 2017, Specht, 2020).

The nanoscale organization of inhibitory synapses is the same in glycinergic neurons in the dorsal and the ventral spinal cord, despite their different embryonic origins. Ventral horn synapses are generally larger, more complex and contain more GlyRs, suggesting that the size of the synapse is differentially regulated in a regional and cell type specific manner to adjust the level of glycinergic inhibition. As such, these synapses may be particularly well adapted to motor circuits, assuring strong and reliable inhibition of the postsynaptic neuron (Alvarez, 2017). At the same time, the long and tortuous perimeter of the postsynaptic specialization is likely to accelerate the dynamic exchange of GlyRs and other synaptic components (Chow et 
403

404

405

406

407

408

409

410

411

412

413

414

415

416

417

418

419

420

421

422

423

424

425

426

427

428

429

430

431

432

433

434

435

436

al., 2017, Santuy et al., 2018), thereby promoting the molecular plasticity at complex inhibitory synapses (Specht, 2020). Whether glycinergic plasticity results from transient changes in GlyR occupancy and/or from the recruitment of extrasynaptic GlyR-gephyrin complexes (Chapdelaine et al., 2021) has not been proven thus far. However, our data suggest that ultimately it is the size and complexity rather than the GlyR packing density that is dynamically regulated. It can further be argued that large and morphologically complex synapses may be particularly well adapted to integrate fast repetitive, or indeed multivesicular release arising from one or more presynaptic sites, thus providing a strong and reliable inhibition of the postsynaptic neuron while maintaining fast neurotransmitter clearance (discussed in (Alvarez, 2017, Rudolph et al., 2015)).

In addition, our data show that GlyR density and occupancy do not change between 2 and 10 months of age, indicating that receptor clustering is fully mature by the earlier time point. Studies of normal aging of spinal cord synapses are scarce, and its effect on receptor organization has not been studied. Broadhead and colleagues (Broadhead et al., 2020) report no difference between the number of excitatory synapses in the ventral horn and only a slight increase in dorsal synapses between 2 to 9 month old mice. Broadly in line with these findings, we found no difference in the number of synapses, synapse area, and GlyR packing density in dorsal and ventral tissue between 2 and 10 months. Thus, glycinergic postsynaptic sites show considerable control over their molecular composition throughout adulthood, further emphasizing the functional significance of their synaptic architecture in both sensory and motor signaling. Our data therefore suggest that a constant GlyR density potentially provides the most efficient organization of the glycinergic postsynaptic site, while enabling the refinement of the size and complexity of the synapse due to ongoing neural activity.

Their molecular organization sets glycinergic synapses apart from excitatory synapses that do not exhibit systematic receptor clustering. Different glutamate receptors are highly variable and occupy separate sub-synaptic domains within the overall postsynaptic density (PSD) (Goncalves et al., 2020). The number of AMPARs at excitatory synapses can range from essentially zero (at silent synapses) to more than 100 (Nusser et al., 1998). Within SSDs, the average AMPAR density has been estimated at around $5000 \mu \mathrm{m}^{-2}$ (Goncalves et al., 2020), although the absolute values will have to be confirmed using quantitative labeling strategies such as the one described here. Interestingly, AMPAR content of SSDs was shown to vary in response to synaptic plasticity without an apparent change in SSD size (Compans et al., 
bioRxiv preprint doi: https://doi.org/10.1101/2021.09.09.459599; this version posted September 13, 2021. The copyright holder for this preprint (which was not certified by peer review) is the author/funder, who has granted bioRxiv a license to display the preprint in perpetuity. It is made available under aCC-BY-NC 4.0 International license.

2021). This suggests that the packing density of AMPARs is not constant even at the nanoscale, which may be the basis for AMPAR plasticity at excitatory synapses.

The neuromotor disease hyperekplexia results from defects in glycinergic inhibition in humans. Several mouse models with analogous mutations in the Glral gene recapitulate the phenotype of exaggerated startle reflexes and muscle stiffness (Schaefer et al., 2018). In general, the mutations in the various mouse models are less well tolerated than in humans and often have lethal phenotypes in homozygotes. Hyperekplexia can be recessively or dominantly inherited in humans, but neither has been shown to cause lethality. The oscillator mouse model, whilst lethal in the homozygous form, displays a relatively mild phenotype in heterozygous animals, with a measurable startle reflex and normal lifespan (Kling et al., 1997). Heterozygous oscillator therefore represents a relevant model for the subtler phenotype in humans and the long-term stability of glycinergic synapses beyond the developmental stage at which lethality occurs in homozygous animals. However, it is not known how the reduced GlyR levels in the Glral ${ }^{\text {spd-ot/WT }}$ hypomorph can affect (and sustain) functional motor networks. Our characterization of the molecular organization of heterozygous oscillator synapses shows that GlyR packing follows the same principle as in wild-type synapses, even though the total number of available functional receptors is reduced, resulting in smaller synapses in the ventral spinal cord. This further emphasizes that the stereotypic arrangement of GlyRs dictates the size of the postsynaptic domain. Most of the synapses that are formed in heterozygous oscillator likely achieve a size threshold capable of sustaining glycinergic signaling without serious motor defects. The lack of fundamental structural changes at glycinergic synapses further suggests that no or only limited compensatory effects take place in oscillator, in agreement with earlier findings that $\alpha 1 \beta$ heteropentameric GlyR complexes cannot be compensated for by other subunit configurations, $\alpha 1$-homopentamers or $\mathrm{GABA}_{\mathrm{A}} \mathrm{Rs}$ (Schaefer et al., 2012). Our findings thus provide a new perspective into the molecular basis of GlyR $\alpha 1$-deficiency in an animal model of human hyperekplexia.

Taken together, our data show that dorsal and ventral synapses are distinct populations. Ventral horn synapses have much higher GlyR copy numbers, even though receptor density is not different. In contrast to the relatively compact, macular synapses in the dorsal horn, ventral horn synapses achieve a greater receptor number by enlarging the synaptic surface, 
470

471

472

473

474

475

476

477

478

479

480

481

482

483

484

485

486

487

488

489

490

491

492

493

494

495

496

497

498

499

500

501

502

503

thus multiplying the sites of signal transmission. These region-specific glycinergic synapse morphologies are likely to underlie functional differences at sensory (dorsal) versus motor (ventral) circuits.

\section{Acknowledgements}

SAM is supported by a Fondation pour la Recherche Médicale (FRM) postdoctoral fellowship (SPF201809007132). NS was supported by funds of the Bavarian State Ministry of Science and the Arts and the University of Würzburg to the Graduate School of Life Sciences (GSLS), University of Würzburg. Research in our laboratory at IBENS is funded by the European Research Council (ERC, Plastinhib), Agence Nationale de la Recherche (ANR, Synaptune and Syntrack), Labex (Memolife) and France-BioImaging (FBI). CV is supported by the Deutsche Forschungsgemeinschaft (DFG, VI586). We acknowledge the use of the EM platform of IBENS. We thank Pascal Legendre (ENP, Inserm) for insightful discussions and Constant Morez and Nadine Schibille for helpful comments on the manuscript. We also thank Marie-Christine Birling and Eve Geronimus from the Institut Clinique de la Souris (ICS, Illkirch, France) for the generation of the C57BL/6N-Glrb ${ }^{\text {tmlIcs }}$ mouse line.

\section{Author contributions}

SAM and CGS planned the experiments; SAM, PR, NS, OG, AC, AD, and CGS performed the experiments; SAM, PR, NS, CV and CGS analyzed the data; CV generated the oscillator strain; CV and AT secured funding; SAM and CGS wrote the manuscript; all authors read and approved the manuscript.

\section{Declaration of interests}

The authors declare no competing interests.

\section{Data and materials availability}

All data are available upon request. 


\section{Materials and Methods}

\section{$505 \quad$ KI mouse model generation}

The knock-in (KI) mouse line C57BL/6N-Glrb ${ }^{\text {tmlIcs }}$ (MGI:6331106) carrying the mutant allele

508 Clinique de la Souris (ICS, Illkirch, France). Flanked by 5' and 3' homology arms of $1.23 \mathrm{~kb}$ and $3.49 \mathrm{~kb}$, respectively, the targeting vector encompassed exon 2 of the Glrb gene with an insertion of the coding sequence of mEos $4 \mathrm{~b}$, as well as a floxed neomycin selection cassette containing the Cre recombinase under control of protamine promoter in intron 2-3. The selection cassette was excised in the $\mathrm{F} 1$ generation by germline expression of $\mathrm{Cre}$, resulting in a single loxP site in intron 2-3 of the Glrb locus (Fig. S1A). The correct insertion of the mEos $4 \mathrm{~b}$ coding sequence was confirmed by sequencing of genomic Glrb ${ }^{\text {Eos/Eos }}$ tail DNA.

515 Genotyping was done using three primers (primer 1: TACCTTCTTGTTTTCTCTCC; primer

516 2: GTCTGTTTTCCCTCATAAGG; primer 3: TCGCTTTTGTAAATGATATGG) for the amplification of the mutant $G l r b^{\text {Eos }}$ (243 bp product) and/or the wild-type alleles (404 bp).

Purified spinal cord mRNA of $G l r b^{\text {Eos/Eos }}, G l r b^{\text {Eos/WT }}$ and $G l r b^{\text {WT/WT }}$ animals was reverse transcribed (primer 6: GGAGTCTAACAGTAATCTGG), and amplified (primer 4: AGGCGCGTCAAACTCGG; primer 5: CCATACCAACCAATGAAAGG). The correct splicing of the mutant transcript was confirmed by sequencing of amplified cDNA. For semiquantitative RT-PCR, the $G l r b^{\text {Eos/Eos }}$ mRNA was spiked with wild-type cDNA at a ratio of

$524 \quad 1: 2,1: 1$ and 2:1 and amplified (Fig. S1B).

All experiments (with the exception of the data in Fig. 4, 5, S1, S2, and S10-12) were carried out with F2 animals resulting from a cross between the KI line C57BL/6N-Glrb ${ }^{\text {tm IIcs }}$ (see above) and a KI mouse line expressing mRFP-tagged gephyrin ( $G p h n^{\mathrm{mRFP}}$ ) (Machado et al., 2011) in the C57BL/6J strain, meaning that the mice had a mixed C57BL/6N x C57BL/6J genetic background. amplification of the mutant Glral ${ }^{\text {spt-ot }}$ (187 bp product) and/or the wild-type alleles (194 bp). 
538 Heterozygous Glrb $^{\mathrm{Eos} / \mathrm{WT}}$ animals were crossed with heterozygous oscillator mice for two

539 generations giving rise to F2 heterozygous oscillator animals that are homozygous for the

$540 G \operatorname{Glr} b^{\text {tml(Eos4)Ics }}$ allele $\left(\right.$ Glra $\left.^{+/ s p d-o t} / G l r b^{\text {Eos/Eos }}\right)$. These animals had a mixed C57BL/6N x

541 C57BL/6J genetic background and were used for the experiments shown in Fig. 4, 5 and S10-

54212.

544 All experiments were in accordance with European Union guidelines and approved by the

545 local veterinary authorities. Animals at IBENS were treated in accordance with the guidelines

546 of the French Ministry of Agriculture and Direction Départementale des Services Vétérinaires

547 de Paris (École Normale Supérieure, Animalerie des Rongeurs, license B 75-05-20).

548 Procedures carried out at the Institute for Clinical Neurobiology were approved by the

549 Veterinäramt der Stadt Würzburg and the Committee on the Ethics of Animal Experiments

550 (Regierung von Unterfranken, Würzburg) and authorized under reference numbers 55.2-

$551 \quad 2531.01-09 / 14 ; 55.2 .2-2532.2-949-31$.

\section{Primary cultures of spinal cord neurons}

554 Cultures of mixed spinal cord neurons were prepared at embryonic day 13 (E13) from C57BL/6J wild-type $G l r b^{\text {WT/WT }}$ and $G l r b^{\text {Eos/Eos }}$ littermates. Spinal cord tissue was trypsinized

556 in trypsin/EDTA $(1 \mathrm{mg} / \mathrm{ml})$ and DNase I (final concentration $0.1 \mathrm{mg} / \mathrm{ml}$ ) for $20 \mathrm{~min}$ at $37^{\circ} \mathrm{C}$.

557 Trypsinization was stopped with $10 \%$ FCS. After trituration, spinal cord neurons were

558 centrifuged at $800 \mathrm{rpm}$ for $10 \mathrm{~min}$. Cells were plated in a $3 \mathrm{~cm}$ dish on polylysine-coated 559 coverslips at a density of $2-2.5 \times 10^{5}$ cells/dish. Neurons were kept at $37^{\circ} \mathrm{C}$ and $5 \% \mathrm{CO}_{2}$ in 560 neurobasal medium containing $2 \mathrm{mM}$ L-glutamine and B27 supplement (Thermo Fisher

561 Scientific) with an exchange of half the medium after 4 days in culture.

\section{Electrophysiological recordings}

564 Spinal cord neuronal cultures at day in vitro 13 (DIV13) were used for patch-clamp 565 recordings in whole-cell configuration. Currents were amplified with a EPC-10 amplifier 566 (HEKA). A laminar flow of increasing agonist concentration $(1,10,30,60,100,300 \mu \mathrm{M}$ 567 glycine, and $100 \mu \mathrm{M}$ glycine/10 $\mu \mathrm{M}$ strychnine) was applied to the suspended cell using an 568 Octaflow II system (ALA Scientific Instruments), allowing 10-30 ms for equilibration. The 569 external buffer for spinal cord neurons was (in mM): $142 \mathrm{NaCl}, 8.1 \mathrm{KCl}, 1 \mathrm{CaCl}_{2}, 6 \mathrm{MgCl}_{2}$, 57010 glucose, 10 HEPES, $\mathrm{pH}$ adjusted to 7.4 with $\mathrm{NaOH}$. To block neuronal excitability and 571 ligand-gated ion channels, the external buffer was complemented with $1 \mu \mathrm{M}$ TTX, $10 \mu \mathrm{M}$ 
bioRxiv preprint doi: https://doi.org/10.1101/2021.09.09.459599; this version posted September 13, 2021. The copyright holder for this preprint (which was not certified by peer review) is the author/funder, who has granted bioRxiv a license to display the preprint in perpetuity. It is made available under aCC-BY-NC 4.0 International license.

bicuculline, $10 \mu \mathrm{M}$ CNQX, and $25 \mu \mathrm{M}$ AP-5. The internal buffer was (in $\mathrm{mM}$ ): $153 \mathrm{KCl}, 1$ $\mathrm{MgCl}_{2}, 5$ EGTA, 10 HEPES, pH adjusted to 7.4 with $\mathrm{CsOH}$. Recording pipettes were fabricated from borosilicate capillaries with an open resistance of 4-6 M $\Omega$. Currents were measured at a holding potential of $-70 \mathrm{mV}$. All experiments were performed at $22^{\circ} \mathrm{C}$. The mean current at each glycine concentration was determined from the peak current amplitudes measured in $\mathrm{N}=10-11$ cells per genotype from three independent preparations (biological replicates).

\section{Spinal cord and brain tissue preparation and vibratome slices}

Mice were sacrificed at 2 and 10 months of age by perfusion with $4 \%$ w/v paraformaldehyde (PFA; Polysciences, EM grade) and 0.1\% v/v glutaraldehyde (GA; Clinisciences) in phosphate buffered saline (PBS, pH 7.4). Perfused animals were kept on ice for $30 \mathrm{~min}$, followed by the dissection of the brain and spinal cord in PBS. Tissue was post-fixed in $4 \%$ w/v PFA in PBS overnight at $4{ }^{\circ} \mathrm{C}$. Brain and spinal cord tissue was rinsed in PBS, cut into smaller segments of thoracic and lumbar regions of the spinal cord and sliced on a vibratome (Leica) at a thickness of $40 \mu \mathrm{m}$ (for confocal imaging) and $300 \mu \mathrm{m}$ (for Tokuyasu preparation), and stored in PBS at $4{ }^{\circ} \mathrm{C}$.

\section{Confocal imaging and analysis}

In order to label neuronal cells in brain slices (Fig. S3) and inhibitory synapses in oscillator and WT littermates (Fig. 4), free-floating vibratome slices (40 $\mu$ m thickness) were blocked and permeabilized in PBS containing 0.25\% Triton X100 (Sigma) and 0.1\% fish gelatin (Sigma) for $1 \mathrm{~h}$, and immunolabeled with either a primary antibody against NeuN (guinea pig polyclonal, 1:500 dilution, Millipore, \#ABN90) or gephyrin (mouse monoclonal, mAb7a, 1:500 dilution, Synaptic Systems, \#147011) in PBS containing 0.1\% Triton X100 and 0.1\% fish gelatin overnight, followed by 3 hour incubation with Alexa Fluor 647-conjugated secondary antibody (donkey anti guinea pig, 1:1000) or Cy3-conjugated secondary antibody (goat anti mouse, 1:1000, Invitrogen) respectively.

Glass slides (Vector Laboratories) were cleaned with 70\% v/v ethanol (Sigma) and vibratome sections were rinsed 3 times in PBS and mounted onto the glass slides. The glass slides were then briefly rinsed in distilled water and dried. A drop of VectaShield (Vector Laboratories) was added to each spinal cord section and covered with a \#1.5 glass coverslip, which was 
sealed with PicoDent Twinsil Speed (equal weights of catalyst and base). Slides were stored at $4{ }^{\circ} \mathrm{C}$ for confocal imaging.

608 Confocal imaging was carried out on a Leica SP8 TCX microscope using a Leica HC PL 609 APO 40x/1.30 NA oil-immersion objective (Leica) and captured in 8-Bit using the Leica 610 LAS-X software with setting HyD3. Images were captured sequentially, with laser 611 illumination at wavelength $570 \mathrm{~nm}$ (mRFP, Cy3) imaged first, followed by laser illumination 612 at $491 \mathrm{~nm}$ wavelength (mEos4). A cross-section from the dorsal horn to the ventral horn was 613 imaged at a zoom of 5, speed of 25, 512 x 512 pixel (px) format. For decay analysis, 8 614 consecutive frames were captured at a zoom of 5, speed 25, 512 x 512 px format. To tile the 615 whole spinal cord, images were captured in at a zoom of 1, speed 100, 256 x 256 px format. 616

617 To ensure alignment of the clusters for the decay traces, images were opened in the image 618 analysis software ICY, and the rigid registration plug-in used, taking the first frame of mRFP619 gephyrin as reference. The mRFP-gephyrin/ and mEos4b-GlyR $\beta$ channels were then 620 separated and the Spot Detector plug-in (de Chaumont et al., 2012) used to identify the 621 clusters in each frame in the mRFP-gephyrin channel, with the identified clusters saved as a region of interest (ROI) set. Using the image analysis software FIJI, the identified mRFP-

623 gephyrin positive cluster ROI-Set was used to identify inhibitory synapses in the first frame of 624 the mEos $4 b-G l y R \beta$ channel. These inhibitory synapses were binned based on mEos $4 \mathrm{~b}$ 625 intensity gray levels $(5-12,13-24,25-49,50-74,75-99,100-124,125-255)$ in frame 1 and a 626 new ROI-Set generated for each bin. Using the frame 1 intensity ROI-Sets, the integrated 627 intensity of mEos $4 \mathrm{~b}$ was then measured at individual clusters across the 8 frames. This enabled decay analysis of mEos $4 b$ intensity at synapses relative to their starting intensity, see 629 Fig. 1C.

631 In order to analyze the intensity of mRFP-gephyrin and mEos $4 b-G l y R \beta$ clusters within the 632 spinal cords from mice of different genotypes, the identified mRFP-gephyrin clusters from the 633 first frame of the decay traces (as measured by the ICY Spot Detector plug-in, see above) 634 were used to measure the relative intensity of mRFP-gephyrin and mEos4b-GlyR $\beta$ clusters at 635 those locations. The ROI-Set of all mRFP-gephyrin positive clusters was used in FIJI to 636 identify inhibitory synapses, where the integrated intensity of mRFP and mEos $4 \mathrm{~b}$ was 637 measured for each synapse (Fig. 1B). 
639 For the cross-sectional analysis, the mRFP-gephyrin/gephyrin-7a clusters were identified

640 across the imaged tissue using the ICY Spot Detector plug-in, as described above, and saved

641 as an ROI-Set. In FIJI the integrated intensity of these identified clusters was measured in the

642 mRFP-gephyrin/gephyrin-7a channel and the mEos4b-GlyR $\beta$ channel (Fig. 1D and 1F).

643

\section{Cryosectioning of sucrose impregnated spinal cord tissue}

645 Sucrose impregnated cryosections were prepared using a ultracryotomy protocol adapted from

646 (Tokuyasu, 1973). The $300 \mu \mathrm{m}$ spinal cord vibratome slices were transferred into a $2.3 \mathrm{M}$

647 sucrose solution in PBS overnight at $4^{\circ} \mathrm{C}$ and micro-dissected to isolate gray matter of the 648 dorsal and the ventral horn region. These fragments were placed individually on top of drops

649 of sucrose solution on aluminium EM pins (Leica) and immediately frozen in liquid nitrogen.

650 Sections of $2 \mu \mathrm{m}$ thickness were sliced on an ultramicrotome (Leica EM UC6) at $-80^{\circ} \mathrm{C}$ and

651 placed onto gridded coverslips (type $1.5 \mathrm{H}$, Ibidi $\mathrm{GmbH}$ ), covered in PBS, and stored at $4^{\circ} \mathrm{C}$

652 for a maximum of 5 days before imaging.

653

\section{Single molecule localization microscopy (SMLM)}

655 Sucrose cryosections on gridded coverslips were rinsed once in PBS, and imaged in PBS.

656 Dual-colour super resolution images were acquired on an inverted Nikon Eclipse Ti

657 microscope with a 100x/1.49 NA oil-immersion objective, with an additional 1.5x lens in the

658 emission path, using an Andor iXon EMCCD camera (16-Bit, $107 \mathrm{~nm}$ pixel size), and NIS-

659 Elements software (Nikon). An emission filter 607/36 was chosen for imaging both mRFP-

660 gephyrin and mEos4b-GlyR $\beta$. Brightfield images were taken of the whole grid square

661 identifying tissue structures. Lamp images were taken of the unconverted mEos4b-GlyR $\beta$ and

662 mRFP-gephyrin (10 frames of $100 \mathrm{~ms}$, ND8). mRFP-gephyrin movies of 10,000 frames were

663 recorded with HiLo $561 \mathrm{~nm}$ continuous laser illumination (output power $50 \% 400 \mathrm{~mW}, 50 \mathrm{~ms}$

664 frames). This was followed by $2 \mathrm{~min}$ of $100 \% 561 \mathrm{~nm}$ laser illumination to ensure all mRFP-

665 gephryin was bleached. Movies of 25,000 frames were recorded with photoconversion of

$666 \mathrm{mEos} 4 \mathrm{~b}-\mathrm{GlyR} \beta$ by $0.5 \mathrm{~ms}$ pulsed $405 \mathrm{~nm}$ laser illumination (gradually increased to $100 \%$ by

667 frame 22,000) with continuous $561 \mathrm{~nm}$ laser illumination (output power $50 \% 400 \mathrm{~mW}, 50 \mathrm{~ms}$

668 frames). The focal plane was maintained using a Nikon perfect focus system. 


\section{SMLM image analysis (SRRF and PALM)}

674 Frames 100-6000 of the mRFP-gephyrin movies were taken for analysis (to remove saturated

675 frames at the beginning and bleached frames at the end) and were drift corrected and

676 reconstructed using NanoJ-SRRF plugin for FIJI (Gustafsson et al., 2016).

677 Quantification of mEos4b-GlyR $\beta$ was carried out using a lab script for MATLAB

678 (Mathworks). The mEos4b single fluorophores were detected by Gaussian fitting. The

679 resulting pointillist images were drift corrected in the $\mathrm{x} / \mathrm{y}$ plane using 5 dense clusters of

680 detections over a sliding window of 2000 frames. Rendered images were produced with a

681 pixel size of $10 \mathrm{~nm}$, sigma 0.01 .

682

683 Fourier ring correlation (FRC) was used to estimate the spatial resolution, by dividing the odd

684 and even frames of a raw mRFP-gephyrin movie and a raw mEos4b-GlyR $\beta$ movie and

685 analyzing the resulting image stacks by SRRF and PALM, respectively. The images

686 reconstructed from the odd and even frames were then compared using the FRC tool of the

687 NanoJ-SQUIRREL plugin for FIJI (Culley et al., 2018).

688

689 The mRFP-gephyrin and mEos $4 \mathrm{~b}-\mathrm{GlyR} \beta$ rendered images were aligned by rigid registration

690 using the FIJI plug-in TurboReg. The co-localization of mRFP-gephyrin and mEos4b-GlyR $\beta$

691 was carried out by individually cropping each synapse as separate images. The FIJI plug-in

692 Intensity correlation quotient (ICQ) was then applied to each synapse (Li et al., 2004). The

693 occupancy analysis was analyzed by thresholding the synapses in the mEos $4 b-G l y R \beta$ images

694 and measuring the intensity of each synapse in both channels. To analyse the PALM mEos4b-

695 GlyR $\beta$ clusters, a lab written script for MATLAB (CountMol; (Patrizio et al., 2017)) was used

696 to identify synapses (minimum number of detections 250, minimum cluster size $200 \mathrm{~nm}$,

697 maximum cluster size $3000 \mathrm{~nm}$ ) and an intensity threshold of 0.1. For molecule conversion,

698 CountMol was used to identify extrasynaptic receptor complexes (minimum number of

699 detections 5, minimum cluster size $10 \mathrm{~nm}$, maximum cluster size $120 \mathrm{~nm}$ ). The number of

700 detections per burst (identified as a minimum of 2 detections, with 1 burst per 1000 frames)

701 and the probability of detection $P_{d e t}=\frac{2}{N_{1} / N_{2}+2}$ were calculated, and used to convert the

702 detections to mEos4b-GlyR $\beta$ molecules (Durisic et al., 2014, Patrizio et al., 2017), see Fig.

703 S7.

704 


\section{Electron microscopy (EM)}

707 Cryosections used for SMLM imaging on gridded coverslips were postfixed by incubation in

$7081 \%$ osmium tetroxide for $1 \mathrm{~h}$ at $4{ }^{\circ} \mathrm{C}$, dehydrated in graded ethanol concentrations, and

709 embedded in araldite epoxy resin. Grid squares imaged in SMLM were identified using the

710 grid pattern imprinted in the resin. Serial ultra-thin $70 \mathrm{~nm}$ sections of these regions were cut,

711 transferred onto formvar-coated EM grids (0.432 mm slot grids) using a UC6 ultramicrotome

712 (Leica). Sections were counterstained with 5\% uranyl acetate in $70 \%$ methanol for 10 min,

713 then washed in distilled water and air dried before observation on a Philips TECNAI 12

714 microscope (Thermo Fisher Scientific).

715

716 For 3D synapse reconstruction, synapses were manually outlined in each serial section image

717 using FIJI, followed by manual rotation and coarse alignment using the software GIMP, then

718 fine alignment of the synaptic area with the Microscopy Image Browser (MIB) software. The

719 aligned images were then opened in IMOD software to generate the 3D reconstruction.

The length of the synaptic junction of identified synapses was measured in high magnification EM images with ImageJ software. The total area of the postsynaptic surface was calculated as the cumulative length of the postsynaptic domain in the entire stack of serial sections

724 multiplied by the thickness of each section $(70 \mathrm{~nm})$. The segmentation index corresponds to

725 the number of gaps in the postsynaptic site that were detected in the $\mathrm{x} / \mathrm{y}$ plane of the images or 726 along the z-axis (i.e. an interruption of the postsynaptic site in one or several continuous 727 sections in the stack), and represents an estimate of the morphological complexity of the 728 synapse.

\section{$730 \quad$ Graphing and statistical analysis}

731 All graphing and statistical analysis was carried out using the software GraphPad Prism v.8

732 for all except the electrophysiology experiments which were carried out in v.9. Data were

733 tested for normality of distribution using D'Agostino-Pearson and Kolmogorov-Smirnov

734 tests. Data is represented as dot plots with median \pm interquartile range (IQR), or histograms, 735 unless otherwise stated. $* \mathrm{p}<0.05, * * \mathrm{p}<0.01, * * * \mathrm{p}<0.001, \mathrm{~ns}=$ not significant. 
bioRxiv preprint doi: https://doi.org/10.1101/2021.09.09.459599; this version posted September 13, 2021. The copyright holder for this preprint (which was not certified by peer review) is the author/funder, who has granted bioRxiv a license to display the preprint in perpetuity. It is made available under aCC-BY-NC 4.0 International license.

\section{References}

Alvarez FJ (2017) Gephyrin and the regulation of synaptic strength and dynamics at glycinergic inhibitory synapses. Brain Res Bull 129: 50-65

Alvarez FJ, Dewey DE, Harrington DA, Fyffe RE (1997) Cell-type specific organization of glycine receptor clusters in the mammalian spinal cord. J Comp Neurol 379: 150-70

Alvarez FJ, Taylor-Blake B, Fyffe RE, De Blas AL, Light AR (1996) Distribution of immunoreactivity for the beta 2 and beta 3 subunits of the GABAA receptor in the mammalian spinal cord. J Comp Neurol 365: 392412

Beato M (2008) The time course of transmitter at glycinergic synapses onto motoneurons. J Neurosci 28: 741225

Bhumbra GS, Bannatyne BA, Watanabe M, Todd AJ, Maxwell DJ, Beato M (2014) The recurrent case for the Renshaw cell. J Neurosci 34: 12919-32

Broadhead MJ, Bonthron C, Arcinas L, Bez S, Zhu F, Goff F, Nylk J, Dholakia K, Gunn-Moore F, Grant SGN, Miles GB (2020) Nanostructural Diversity of Synapses in the Mammalian Spinal Cord. Sci Rep 10: 8189

Buckwalter MS, Cook SA, Davisson MT, White WF, Camper SA (1994) A frameshift mutation in the mouse alpha 1 glycine receptor gene (Glra1) results in progressive neurological symptoms and juvenile death. Hum Mol Genet 3: 2025-30

Chapdelaine T, Hakim V, Triller A, Ranft J, Specht CG (2021) Reciprocal stabilization of glycine receptors and gephyrin scaffold proteins at inhibitory synapses. Biophys J 120: 805-817

Chery N, de Koninck Y (1999) Junctional versus extrajunctional glycine and GABA(A) receptor-mediated IPSCs in identified lamina I neurons of the adult rat spinal cord. J Neurosci 19: 7342-55

Chow DM, Zuchowski KA, Fetcho JR (2017) In vivo measurement of glycine receptor turnover and synaptic size reveals differences between functional classes of motoneurons in zebrafish. Curr Biol 27: 1173-1183

Chung SK, Bode A, Cushion TD, Thomas RH, Hunt C, Wood SE, Pickrell WO, Drew CJ, Yamashita S, Shiang R, Leiz S, Longardt AC, Raile V, Weschke B, Puri RD, Verma IC, Harvey RJ, Ratnasinghe DD, Parker M, Rittey C et al. (2013) GLRB is the third major gene of effect in hyperekplexia. Hum Mol Genet 22: 927-40

Chung SK, Vanbellinghen JF, Mullins JG, Robinson A, Hantke J, Hammond CL, Gilbert DF, Freilinger M, Ryan M, Kruer MC, Masri A, Gurses C, Ferrie C, Harvey K, Shiang R, Christodoulou J, Andermann F, Andermann E, Thomas RH, Harvey RJ et al. (2010) Pathophysiological mechanisms of dominant and recessive GLRA1 mutations in hyperekplexia. J Neurosci 30: 9612-20

Compans B, Camus C, Kallergi E, Sposini S, Martineau M, Butler C, Kechkar A, Klaassen RV, Retailleau N, Sejnowski TJ, Smit AB, Sibarita JB, Bartol TM, Jr., Perrais D, Nikoletopoulou V, Choquet D, Hosy E (2021) NMDAR-dependent long-term depression is associated with increased short term plasticity through autophagy mediated loss of PSD-95. Nat Commun 12: 2849

Crosby KC, Gookin SE, Garcia JD, Hahm KM, Dell'Acqua ML, Smith KR (2019) Nanoscale subsynaptic domains underlie the organization of the inhibitory synapse. Cell Rep 26: 3284-3297 e3

Culley S, Albrecht D, Jacobs C, Pereira PM, Leterrier C, Mercer J, Henriques R (2018) Quantitative mapping and minimization of super-resolution optical imaging artifacts. Nat Methods 15: 263-266

de Chaumont F, Dallongeville S, Chenouard N, Herve N, Pop S, Provoost T, Meas-Yedid V, Pankajakshan P, Lecomte T, Le Montagner Y, Lagache T, Dufour A, Olivo-Marin JC (2012) Icy: an open bioimage informatics platform for extended reproducible research. Nat Methods 9: 690-6

Durisic N, Laparra-Cuervo L, Sandoval-Alvarez A, Borbely JS, Lakadamyali M (2014) Single-molecule evaluation of fluorescent protein photoactivation efficiency using an in vivo nanotemplate. Nat Methods 11: $156-62$

Dzyubenko E, Rozenberg A, Hermann DM, Faissner A (2016) Colocalization of synapse marker proteins evaluated by STED-microscopy reveals patterns of neuronal synapse distribution in vitro. J Neurosci Methods 273: 149-159

Fujita M, Sato K, Sato M, Inoue T, Kozuka T, Tohyama M (1991) Regional distribution of the cells expressing glycine receptor beta subunit mRNA in the rat brain. Brain Res 560: 23-37

Goncalves J, Bartol TM, Camus C, Levet F, Menegolla AP, Sejnowski TJ, Sibarita JB, Vivaudou M, Choquet D, Hosy E (2020) Nanoscale co-organization and coactivation of AMPAR, NMDAR, and mGluR at excitatory synapses. Proc Natl Acad Sci U S A 117: 14503-14511

Gustafsson N, Culley S, Ashdown G, Owen DM, Pereira PM, Henriques R (2016) Fast live-cell conventional fluorophore nanoscopy with ImageJ through super-resolution radial fluctuations. Nat Commun 7: 12471 
bioRxiv preprint doi: https://doi.org/10.1101/2021.09.09.459599; this version posted September 13, 2021. The copyright holder for this preprint (which was not certified by peer review) is the author/funder, who has granted bioRxiv a license to display the preprint in perpetuity. It is made available under aCC-BY-NC 4.0 International license.

Haas KT, Compans B, Letellier M, Bartol TM, Grillo-Bosch D, Sejnowski TJ, Sainlos M, Choquet D, Thoumine O, Hosy E (2018) Pre-post synaptic alignment through neuroligin-1 tunes synaptic transmission efficiency. Elife 7

Harvey RJ, Depner UB, Wassle H, Ahmadi S, Heindl C, Reinold H, Smart TG, Harvey K, Schutz B, Abo-Salem OM, Zimmer A, Poisbeau P, Welzl H, Wolfer DP, Betz H, Zeilhofer HU, Muller U (2004) GlyR alpha3: an essential target for spinal PGE2-mediated inflammatory pain sensitization. Science 304: 884-7

Kim EY, Schrader N, Smolinsky B, Bedet C, Vannier C, Schwarz G, Schindelin H (2006) Deciphering the structural framework of glycine receptor anchoring by gephyrin. Embo J 25: 1385-95

Kling C, Koch M, Saul B, Becker CM (1997) The frameshift mutation oscillator (Glra1(spd-ot)) produces a complete loss of glycine receptor alpha1-polypeptide in mouse central nervous system. Neuroscience 78: 411-7

Legendre P (1998) A reluctant gating mode of glycine receptor channels determines the time course of inhibitory miniature synaptic events in zebrafish hindbrain neurons. J Neurosci 18: 2856-70

Li Q, Lau A, Morris TJ, Guo L, Fordyce CB, Stanley EF (2004) A syntaxin 1, Galpha(o), and N-type calcium channel complex at a presynaptic nerve terminal: analysis by quantitative immunocolocalization. J Neurosci 24: 4070-81

Lim R, Alvarez FJ, Walmsley B (1999) Quantal size is correlated with receptor cluster area at glycinergic synapses in the rat brainstem. J Physiol 516 ( Pt 2): 505-12

Liu YT, Tao CL, Zhang X, Xia W, Shi DQ, Qi L, Xu C, Sun R, Li XW, Lau PM, Zhou ZH, Bi GQ (2020) Mesophasic organization of GABA(A) receptors in hippocampal inhibitory synapses. Nat Neurosci

Lorenzo LE, Godin AG, Wang F, St-Louis M, Carbonetto S, Wiseman PW, Ribeiro-da-Silva A, De Koninck Y (2014) Gephyrin clusters are absent from small diameter primary afferent terminals despite the presence of GABA(A) receptors. J Neurosci 34: 8300-17

Lu DC, Niu T, Alaynick WA (2015) Molecular and cellular development of spinal cord locomotor circuitry. Front Mol Neurosci 8: 25

Lushnikova I, Skibo G, Muller D, Nikonenko I (2011) Excitatory synaptic activity is associated with a rapid structural plasticity of inhibitory synapses on hippocampal CA1 pyramidal cells. Neuropharmacology 60: 757-64

MacGillavry Harold D, Song Y, Raghavachari S, Blanpied Thomas A (2013) Nanoscale Scaffolding Domains within the Postsynaptic Density Concentrate Synaptic AMPA Receptors. Neuron 78: 615-622

Machado P, Rostaing P, Guigonis JM, Renner M, Dumoulin A, Samson M, Vannier C, Triller A (2011) Heat shock cognate protein 70 regulates gephyrin clustering. J Neurosci 31: 3-14

Malosio ML, Marquèze-Pouey B, Kuhse J, Betz H (1991) Widespread expression of glycine receptor subunit mRNAs in the adult and developing rat brain. Embo j 10: 2401-9

Maric HM, Mukherjee J, Tretter V, Moss SJ, Schindelin H (2011) Gephyrin-mediated gamma-aminobutyric acid type A and glycine receptor clustering relies on a common binding site. J Biol Chem 286: 42105-14

Meyer G, Kirsch J, Betz H, Langosch D (1995) Identification of a gephyrin binding motif on the glycine receptor beta subunit. Neuron 15: 563-72

Nusser Z, Cull-Candy S, Farrant M (1997) Differences in synaptic GABA(A) receptor number underlie variation in GABA mini amplitude. Neuron 19: 697-709

Nusser Z, Lujan R, Laube G, Roberts JD, Molnar E, Somogyi P (1998) Cell type and pathway dependence of synaptic AMPA receptor number and variability in the hippocampus. Neuron 21: 545-59

Oleskevich S, Alvarez FJ, Walmsley B (1999) Glycinergic miniature synaptic currents and receptor cluster sizes differ between spinal cord interneurons. J Neurophysiol 82: 312-9

Patrizio A, Renner M, Pizzarelli R, Triller A, Specht CG (2017) Alpha subunit-dependent glycine receptor clustering and regulation of synaptic receptor numbers. Sci Rep 7: 10899

Pennacchietti F, Vascon S, Nieus T, Rosillo C, Das S, Tyagarajan SK, Diaspro A, Del Bue A, Petrini EM, Barberis A, Cella Zanacchi F (2017) Nanoscale molecular reorganization of the inhibitory postsynaptic density is a determinant of GABAergic synaptic potentiation. J Neurosci 37: 1747-1756

Peters A, Palay SL (1996) The morphology of synapses. J Neurocytol 25: 687-700

Rudolph S, Tsai MC, von Gersdorff H, Wadiche JI (2015) The ubiquitous nature of multivesicular release. Trends Neurosci 38: 428-38

Santuy A, Rodriguez JR, DeFelipe J, Merchan-Perez A (2018) Study of the size and shape of synapses in the juvenile rat somatosensory cortex with $3 \mathrm{D}$ electron microscopy. eNeuro 5 
bioRxiv preprint doi: https://doi.org/10.1101/2021.09.09.459599; this version posted September 13, 2021. The copyright holder for this preprint (which was not certified by peer review) is the author/funder, who has granted bioRxiv a license to display the preprint in perpetuity. It is made available under aCC-BY-NC 4.0 International license.

Schaefer N, Langlhofer G, Kluck CJ, Villmann C (2013) Glycine receptor mouse mutants: model systems for human hyperekplexia. Br J Pharmacol 170: 933-52

Schaefer N, Roemer V, Janzen D, Villmann C (2018) Impaired glycine receptor trafficking in neurological diseases. Front Mol Neurosci 11: 291

Schaefer N, Vogel N, Villmann C (2012) Glycine receptor mutants of the mouse: what are possible routes of inhibitory compensation? Front Mol Neurosci 5: 98

Singer JH, Berger AJ (1999) Contribution of single-channel properties to the time course and amplitude variance of quantal glycine currents recorded in rat motoneurons. J Neurophysiol 81: 1608-16

Specht CG (2020) Fractional occupancy of synaptic binding sites and the molecular plasticity of inhibitory synapses. Neuropharmacology 169: 107493

Specht CG, Izeddin I, Rodriguez PC, El Beheiry M, Rostaing P, Darzacq X, Dahan M, Triller A (2013) Quantitative nanoscopy of inhibitory synapses: counting gephyrin molecules and receptor binding sites. Neuron 79: 308-21

Takahashi T (1992) The minimal inhibitory synaptic currents evoked in neonatal rat motoneurones. J Physiol 450: 593-611

860 Tang AH, Chen H, Li TP, Metzbower SR, MacGillavry HD, Blanpied TA (2016) A trans-synaptic nanocolumn aligns neurotransmitter release to receptors. Nature 536: 210-4

Todd AJ, Watt C, Spike RC, Sieghart W (1996) Colocalization of GABA, glycine, and their receptors at synapses in the rat spinal cord. J Neurosci 16: 974-82

864 Tokuyasu KT (1973) A technique for ultracryotomy of cell suspensions and tissues. J Cell Biol 57: 551-65

865 Weltzien F, Puller C, O'Sullivan GA, Paarmann I, Betz H (2012) Distribution of the glycine receptor betasubunit in the mouse CNS as revealed by a novel monoclonal antibody. J Comp Neurol 520: 3962-81

Yang X, Le Corronc H, Legendre P, Triller A, Specht CG (2021) Differential regulation of glycinergic and GABAergic nanocolumns at mixed inhibitory synapses. EMBO Rep 22: e52154

Yang X, Specht CG (2019) Subsynaptic domains in super-resolution microscopy: The treachery of images. Front Mol Neurosci 12: 161

Zeilhofer HU, Studler B, Arabadzisz D, Schweizer C, Ahmadi S, Layh B, Bosl MR, Fritschy JM (2005) Glycinergic neurons expressing enhanced green fluorescent protein in bacterial artificial chromosome transgenic mice. J Comp Neurol 482: 123-41 
bioRxiv preprint doi: https://doi org/10.1101/2021.09.09,459599; this version posted September 13, 2021. The copyright holder for this preprint (which was not certified by peer review) is the author/funder, who has granted bioRxiv a license to display the preprint in perpetuity. It is made available under aCC-BY-NC 4.0 International license.

\section{Figures and Legends}
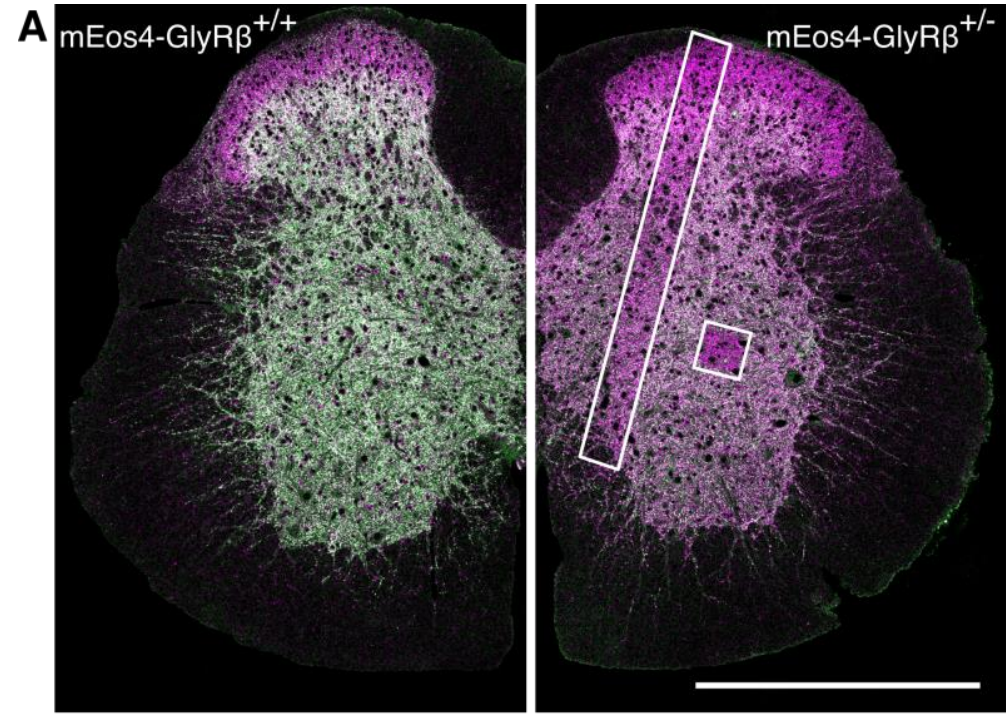

C

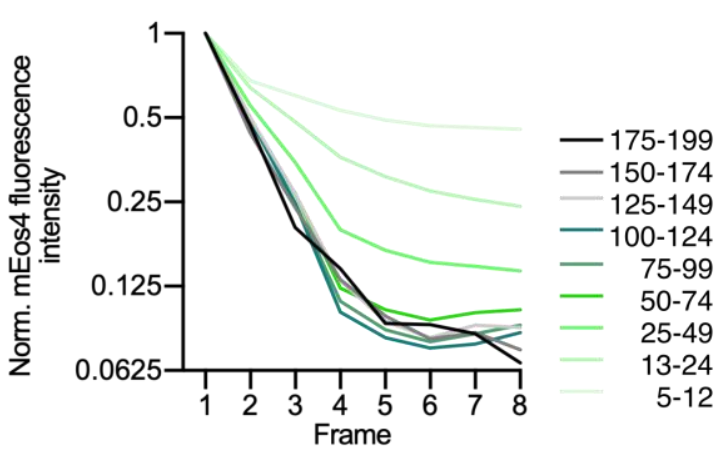

E
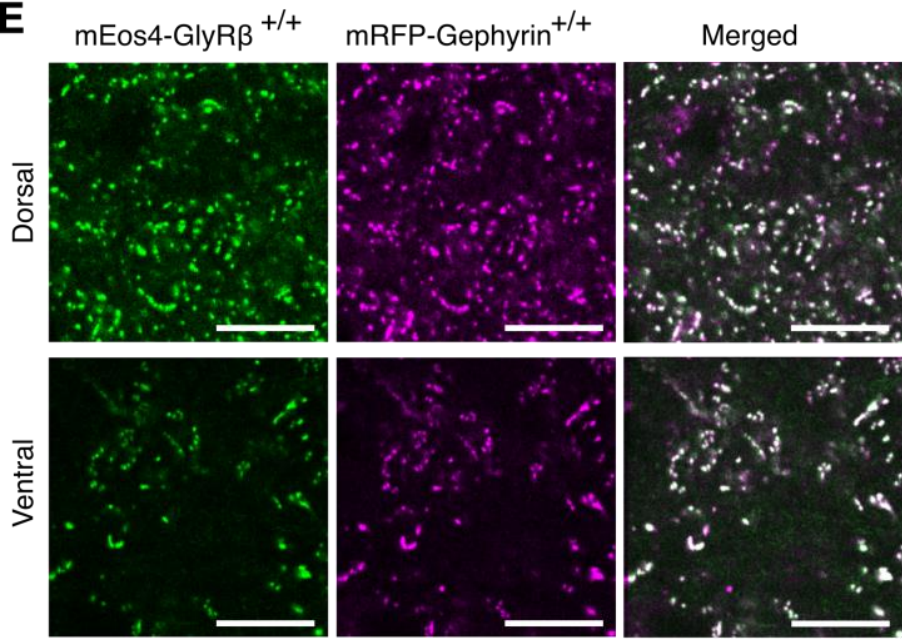

878

879

880

881

882

883

884
B
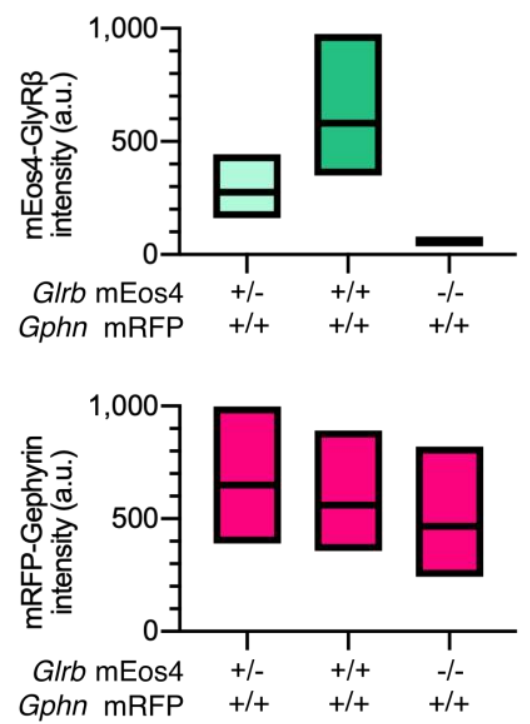

D
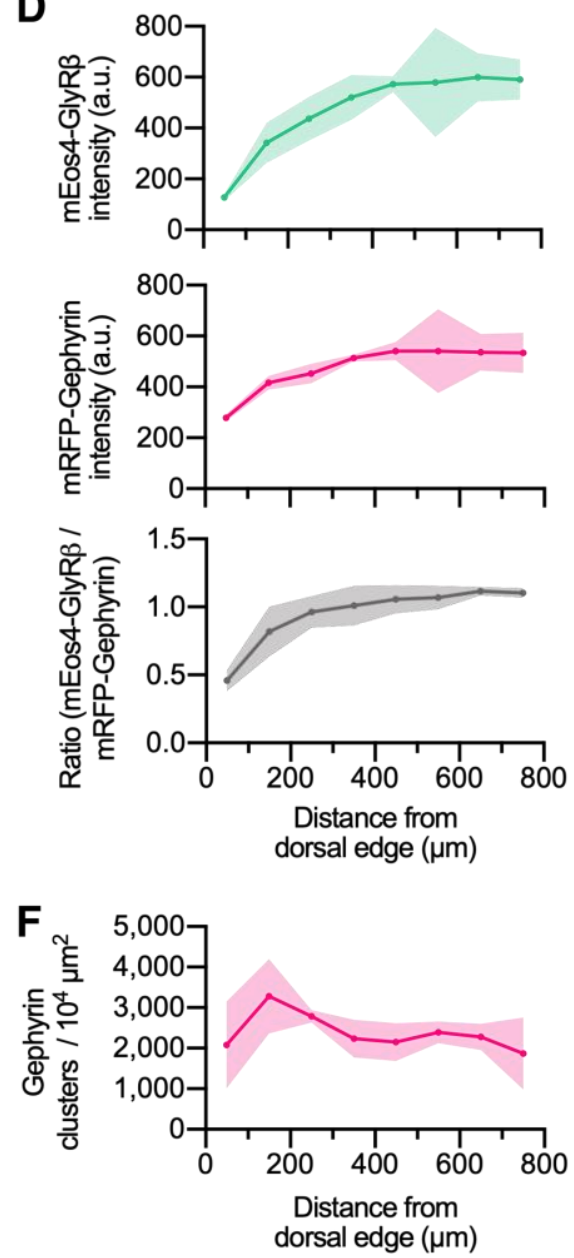

Fig. 1. Quantitative confocal imaging of endogenous GlyRs in spinal cord tissue. (A) Representative confocal images of $40 \mu \mathrm{m}$ spinal cord tissue sections from homozygous $(+/+)$ and heterozygous (+/-) mEos $4 b-G l y R \beta$ mice (green). Both mice are homozygous for mRFPgephyrin (magenta). Scale bar $=0.5 \mathrm{~mm}$. (B) Quantification of mEos $4 \mathrm{~b}-\mathrm{GlyR} \beta$ and mRFPgephyrin fluorescent intensity of homozygous and heterozygous 2 month old animals 
885 measured in the area indicated by the white square in (A). Plots show median and quartiles. $\mathrm{N}$

$886=5-6$ images from 5-6 tissue slices per genotype from 2 mice per age group. (C) Normalized

887 fluorescent decay traces of homozygous mEos $4 \mathrm{~b}$ measured in the area indicated by the white

888 square in (A) over 8 consecutive frames. Intensities were binned in the first image and tracked

889 on an individual synapse basis across the 8 frames. (D) Mean intensity $\pm 95 \%$ confidence

890 interval of mEos 4 b-GlyR $\beta$ and mRFP-gephyrin measured from distal edge of spinal cord in 2

891 month old homozygous mice. Intensities measured in region as indicated by white rectangle

892 in (A). $\mathrm{N}=3$ images from 3 tissue slices from 2 mice per condition. (E) Representative

893 images of homozygous mEos4b-GlyR $\beta$ and mRFP-gephyrin at dorsal and ventral synapses.

894 Scale bar $=10 \mu \mathrm{m}$. (F) Quantification of numbers of gephyrin clusters across the spinal cord.

895 Plot shows mean $\pm 95 \%$ confidence interval. $\mathrm{N}=3$ images from 3 tissue slices from 2 mice

896 per condition. 
bioRxiv preprint doi: https://doi org/101101/2021.09 09 459599; this version posted September 13, 2021. The copyright holder for this preprint (which was not certified by peer review) is the author/funder, who has granted bioRxiv a license to display the preprint in perpetuity. It is made available under aCC-BY-NC 4.0 International license.

A
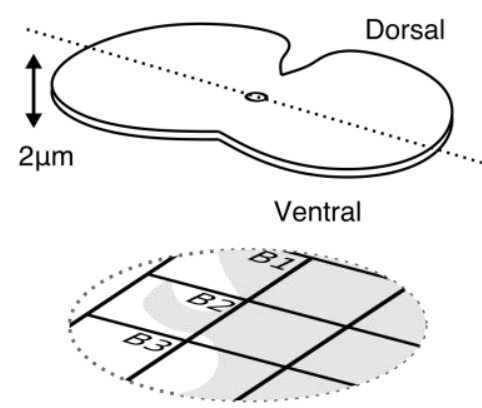

C

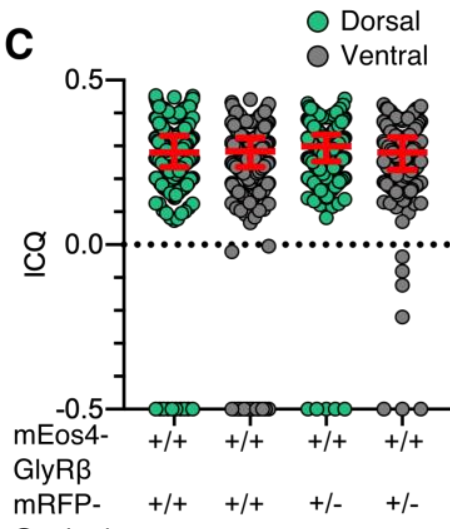

Gephyrin

$\mathbf{F}$

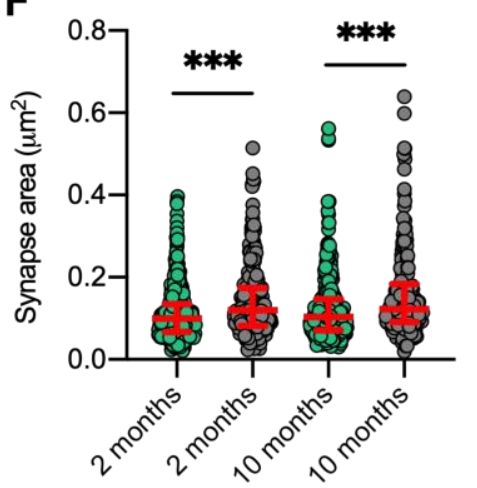

H

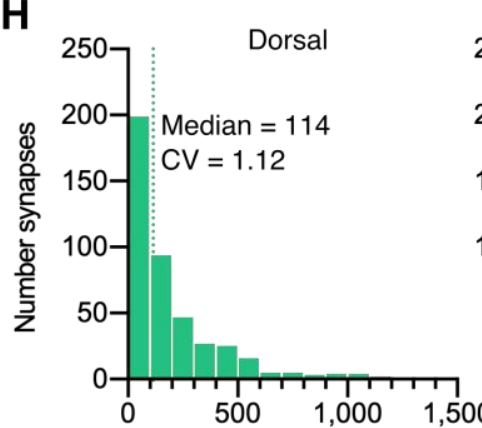

GlyR/synapse
B
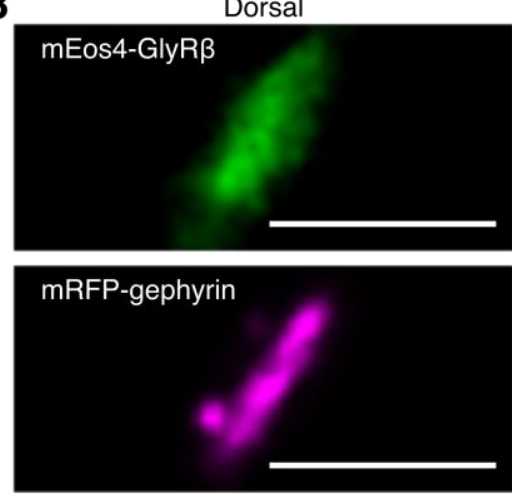

Dorsal: Spearman $r=0.80$

D

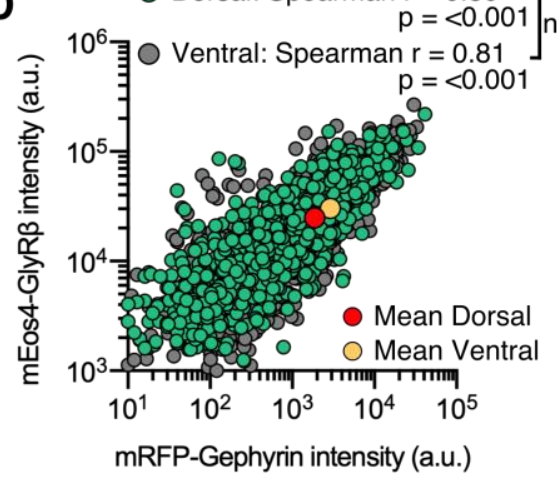

G

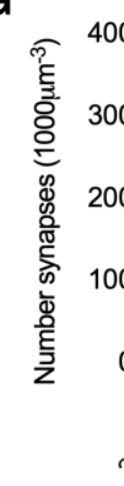

898

899

900

901

902

903

904

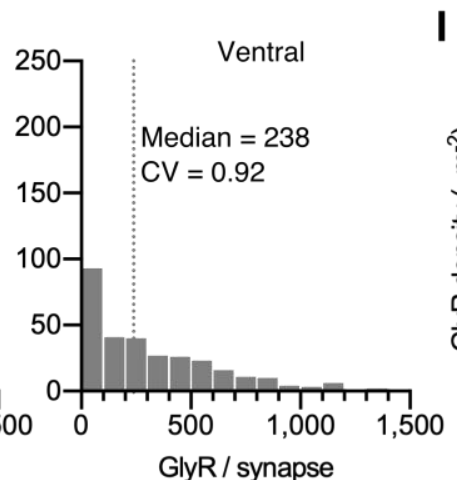

GlyR/ synapse

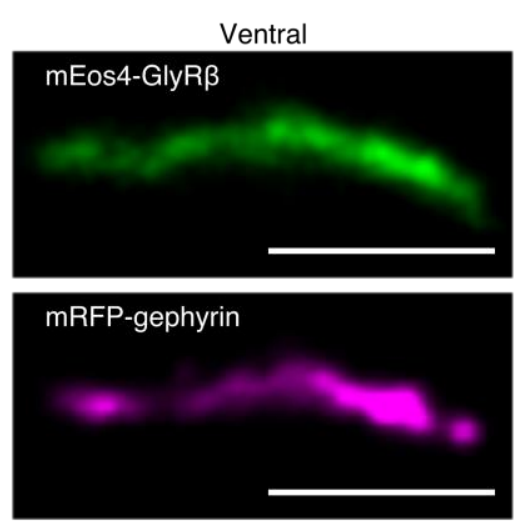

E
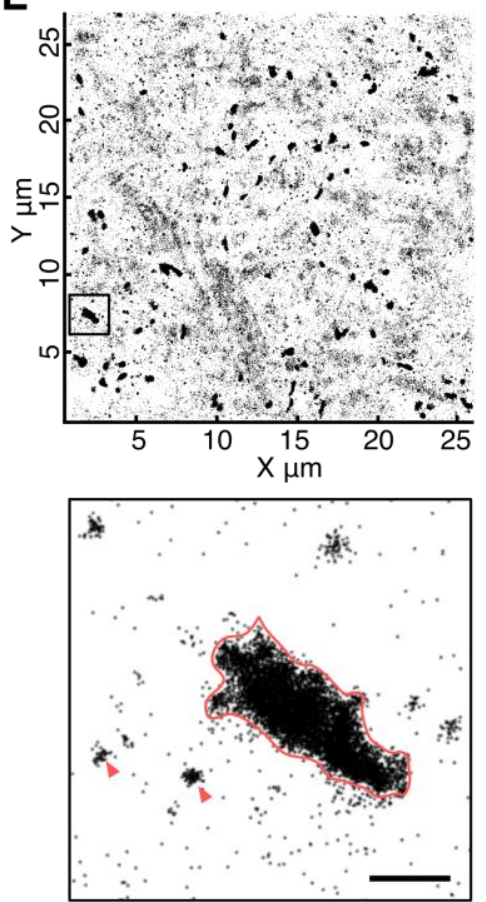

Fig. 2. Dual-color super-resolution imaging of mEos4b-GlyR $\beta$ and mRFP-gephyrin. (A) $2 \mu \mathrm{m}$ cryosections of spinal cord tissue were cut from dorsal and ventral tissue and placed on gridded glass coverslips. (B) Representative PALM reconstruction of mEos $4 b-G l y R \beta$ and SRRF reconstruction of mRFP-gephyrin at single dorsal and ventral synapses. Scale bar $=$ $500 \mathrm{~nm}$. (C) Intensity correlation quotient (ICQ) of mEos4b-GlyR $\beta$ and mRFP-gephyrin in 
bioRxiv preprint doi: https://doi.org/10.1101/2021.09.09.459599; this version posted September 13, 2021. The copyright holder for this preprint (which was not certified by peer review) is the author/funder, who has granted bioRxiv a license to display the preprint in perpetuity. It is made available under aCC-BY-NC 4.0 International license.

905 heterozygous and homozygous 2 month old mice. Plot shows median \pm interquartile range. $\mathrm{N}$ $906=357-604$ synapses from 23 dorsal and 23 ventral images from 9 and 8 tissue slices

907 respectively from 2 mice per condition. (D) Quantification of GlyR-gephyrin occupancy in 2 908 month old homozygous mice $\left(G l r b^{\text {Eos/Eos }} / G p h n^{\mathrm{mRFP} / \mathrm{mRFP}}\right)$. Non-parametric Spearman's rank 909 shows the same positive correlation at dorsal and ventral synapses. $\mathrm{N}=1115$ dorsal synapses 910 and 1107 ventral synapses. (E) Pointillist reconstruction of mEos4b-GlyR $\beta$ detections. Insert 911 shows a single synapse; red arrows indicate extrasynaptic receptor complexes. Scale bar $=$ $912500 \mathrm{~nm}$. (F) Area of dorsal vs ventral synapses in 2 and 10 month old homozygous mice. Plot 913 shows median \pm interquartile range. $\mathrm{N}=234-433$ synapses from 20-23 images from 7-9 tissue 914 slices from 2 mice per age per condition. Nonparametric Kruskal-Wallis ANOVA with 915 Dunn's multiple comparison test. (G) Number of synapses in dorsal and ventral tissue in 2 916 and 10 month old homozygous mice. Plot shows median \pm interquartile range. $\mathrm{N}=20-23$ 917 images from 7-9 tissue slices from 2 mice per age per condition. Nonparametric Kruskal918 Wallis ANOVA with Dunn's multiple comparison test. (H) Histogram of the number of 919 GlyRs per synapse calculated from the molecular conversion of detections (see Fig. S6 and 920 S7) in 2 month old homozygous mice. $\mathrm{N}=433$ dorsal synapses and 304 ventral synapses 921 from 23 dorsal and 23 ventral images from 9 and 8 tissue slices respectively from 2 mice. CV $922=$ coefficient of variation. (I) Scatter plot of GlyR density vs synapse area in 2 month old homozygous mice shows no difference between dorsal and ventral synapse densities. $N=433$ dorsal synapses and 304 ventral synapses. ${ }^{*} \mathrm{p}<0.05$, ** $\mathrm{p}<0.01, * * * \mathrm{p}<0.001$. 
bioRxiv preprint doi: https://doi org/10.1101/2021.09.09,459599; this version posted September 13, 2021. The copyright holder for this preprint (which was not certified by peer review) is the author/funder, who has granted bioRxiv a license to display the preprint in perpetuity. It is made available under aCC-BY-NC 4.0 International license.

A

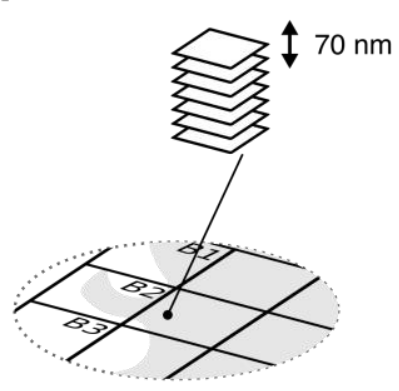

$\mathbf{C}$

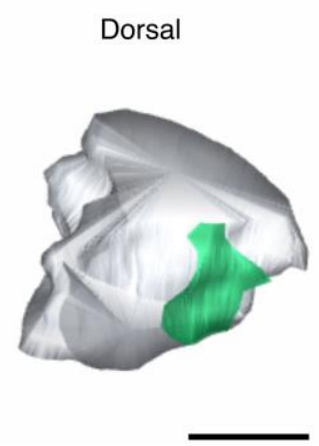

E

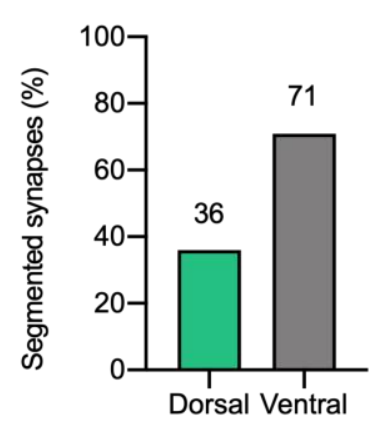

H

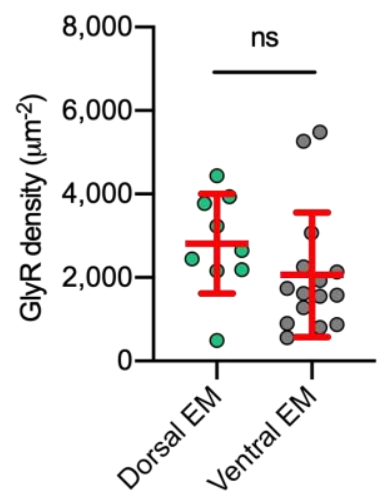

B

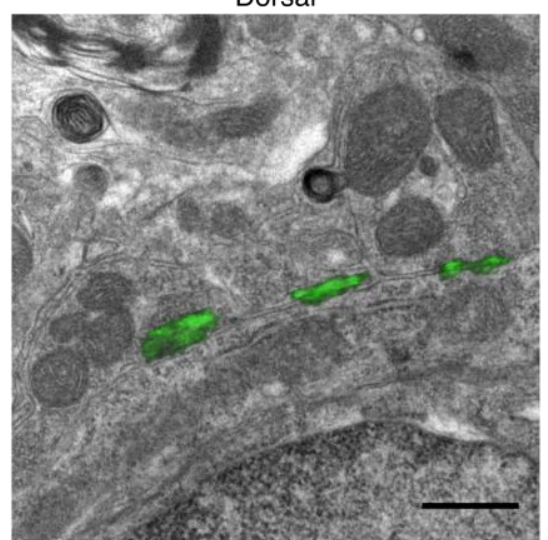

Ventral

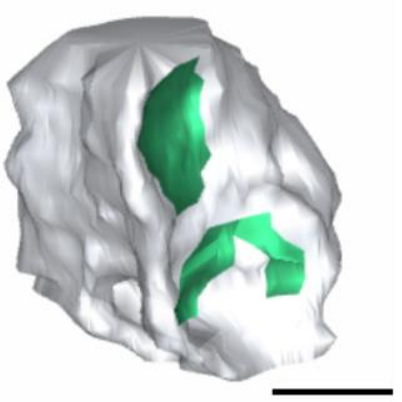

$\mathbf{F}$
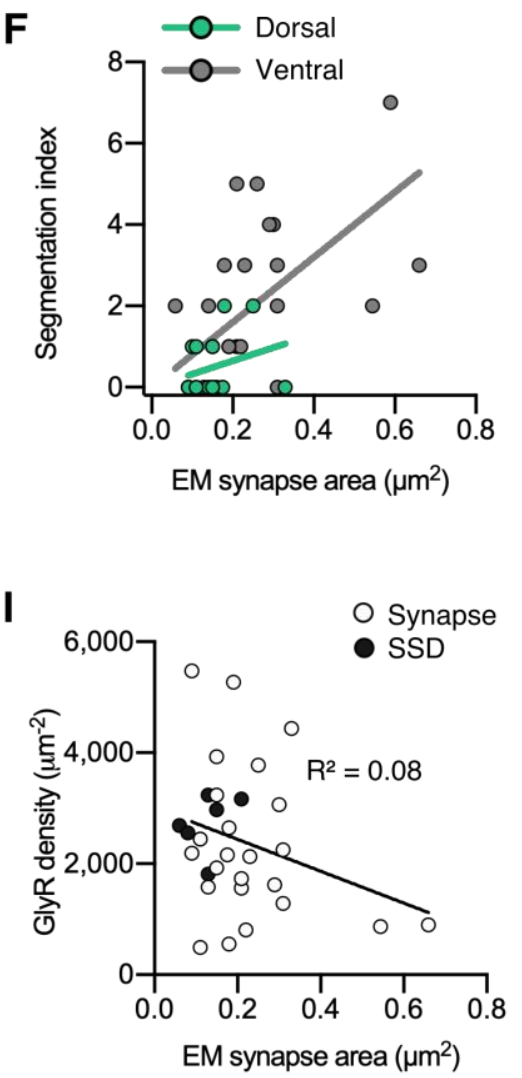

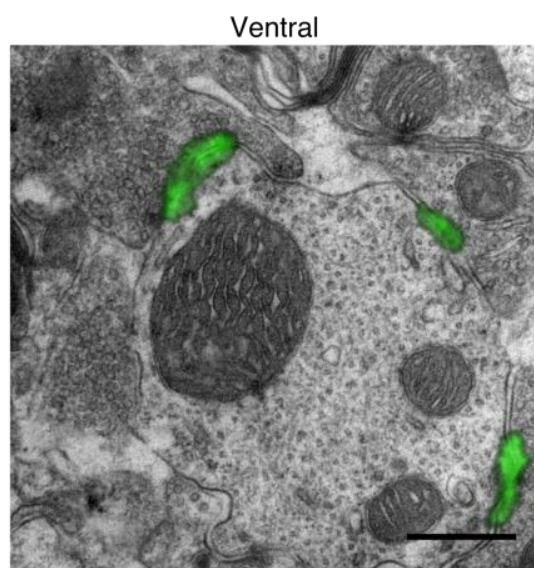

D

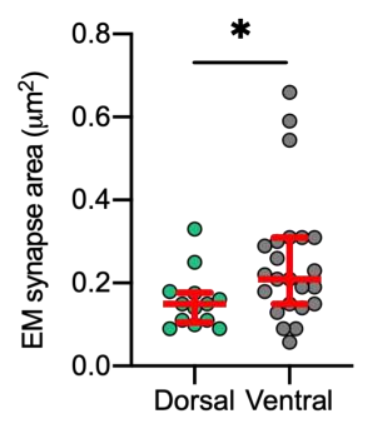

G
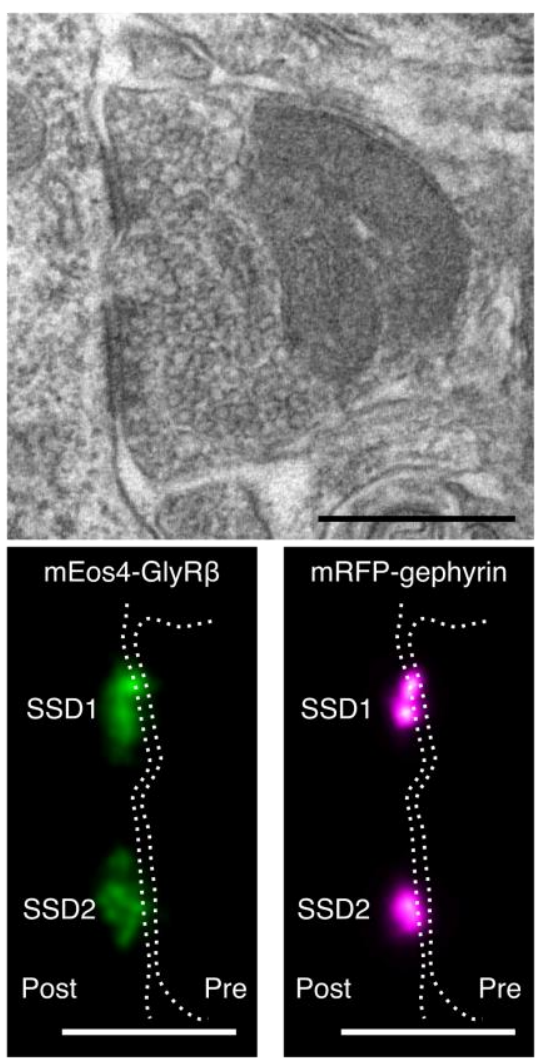

Fig. 3. Quantitative SR-CLEM of endogenous GlyR molecular organization. (A) Samples used for PALM were re-sectioned as serial ultra-thin $70 \mathrm{~nm}$ sections for CLEM. (B) Representative dorsal and ventral synapses imaged with PALM (mEos4b-GlyR $\beta$; green) and super-imposed with their corresponding electron micrographs. Scale bar $=500 \mathrm{~nm}$. (C) 
bioRxiv preprint doi: https://doi org/10.1101/2021.09.09.459599; this version posted September 13, 2021. The copyright holder for this preprint (which was not certified by peer review) is the author/funder, who has granted bioRxiv a license to display the preprint in perpetuity. It is made available under aCC-BY-NC 4.0 International license.

932 Representative 3D reconstructions of dorsal and ventral synapses. Green = postsynaptic site, 933 gray = presynaptic bouton. Scale bar $=500 \mathrm{~nm}$. (D) Area of dorsal and ventral synapses 934 measured by EM. Plot shows median \pm interquartile range. Nonparametric unpaired two935 tailed t-test, Mann-Whitney post hoc. (E) Percentage of total synapses measured in EM with 936 segmented shapes. (F) Comparison of segmentation index with synaptic area in dorsal and ventral synapses. $(\mathrm{G})$ Juxtaposition of a raw electron micrograph and reconstructed

938 PALM/SRRF images of sub-synaptic domains (SSDs) in the same ventral synapse. Scale bar $939=500 \mathrm{~nm}$. $(\mathrm{H})$ Analysis of GlyR density following correction for EM area measurements. Plot 940 shows mean \pm SD. (I) Combined scatter plot of dorsal and ventral synapse densities shows 941 density is independent of synapse size. White = all synapses, black = SSDs. $\mathrm{N}=13$ dorsal and 94223 ventral synapses from 2 mice. ${ }^{*} \mathrm{p}<0.05$, ns $=$ not significant. 
bioRxiv preprint doi: https://doi org/10.1101/2021.09.09.459599; this version posted September 13, 2021. The copyright holder for this preprint (which was not certified by peer review) is the author/funder, who has granted bioRxiv a license to display the preprint in perpetuity. It is made available under aCC-BY-NC 4.0 International license.

A

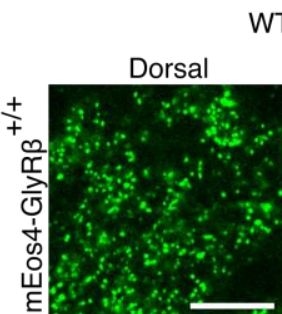

$\mathrm{WT}^{+/+}$
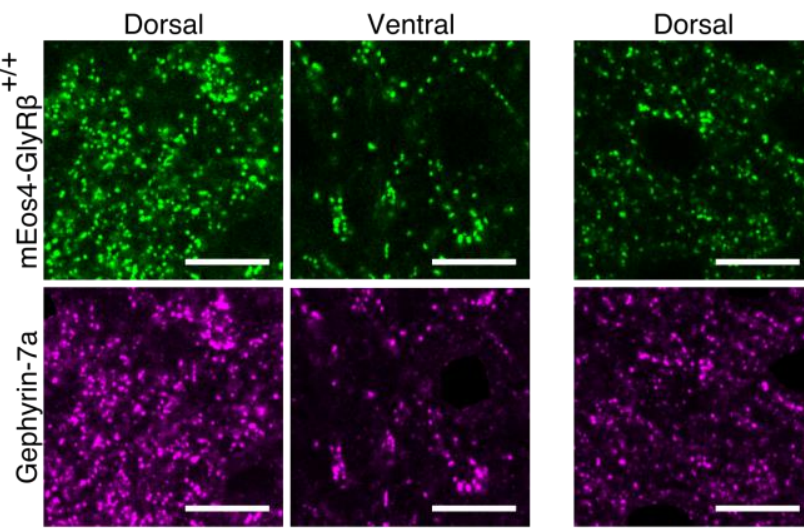

Oscillator $+/-$
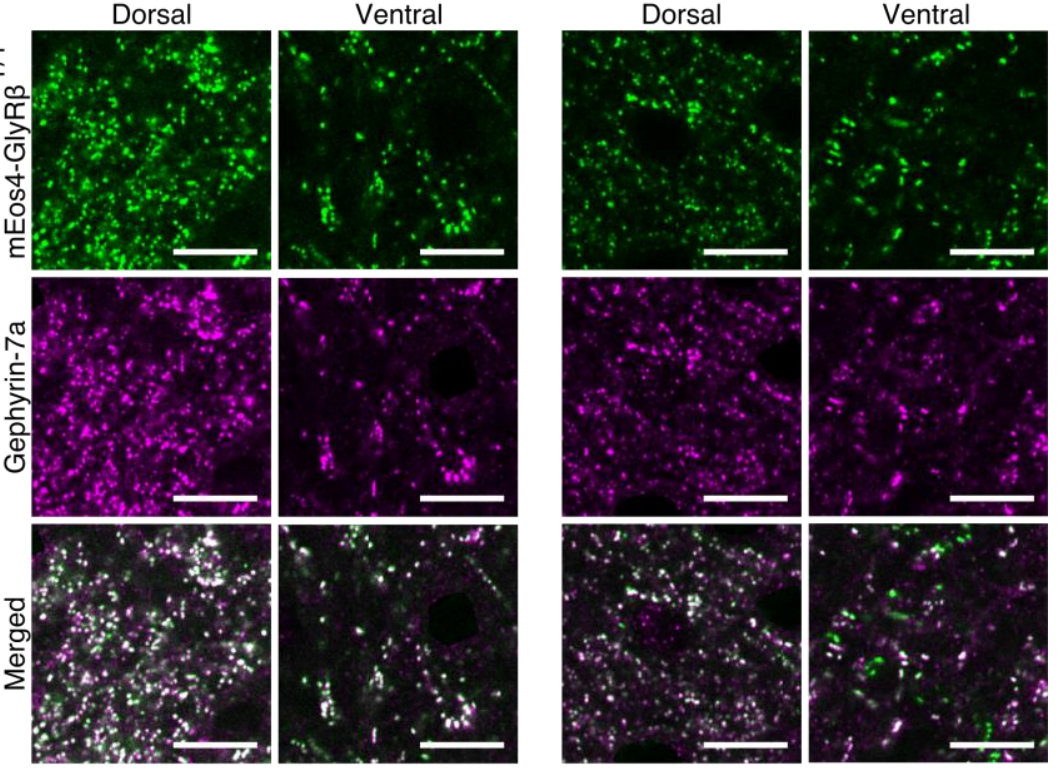

B
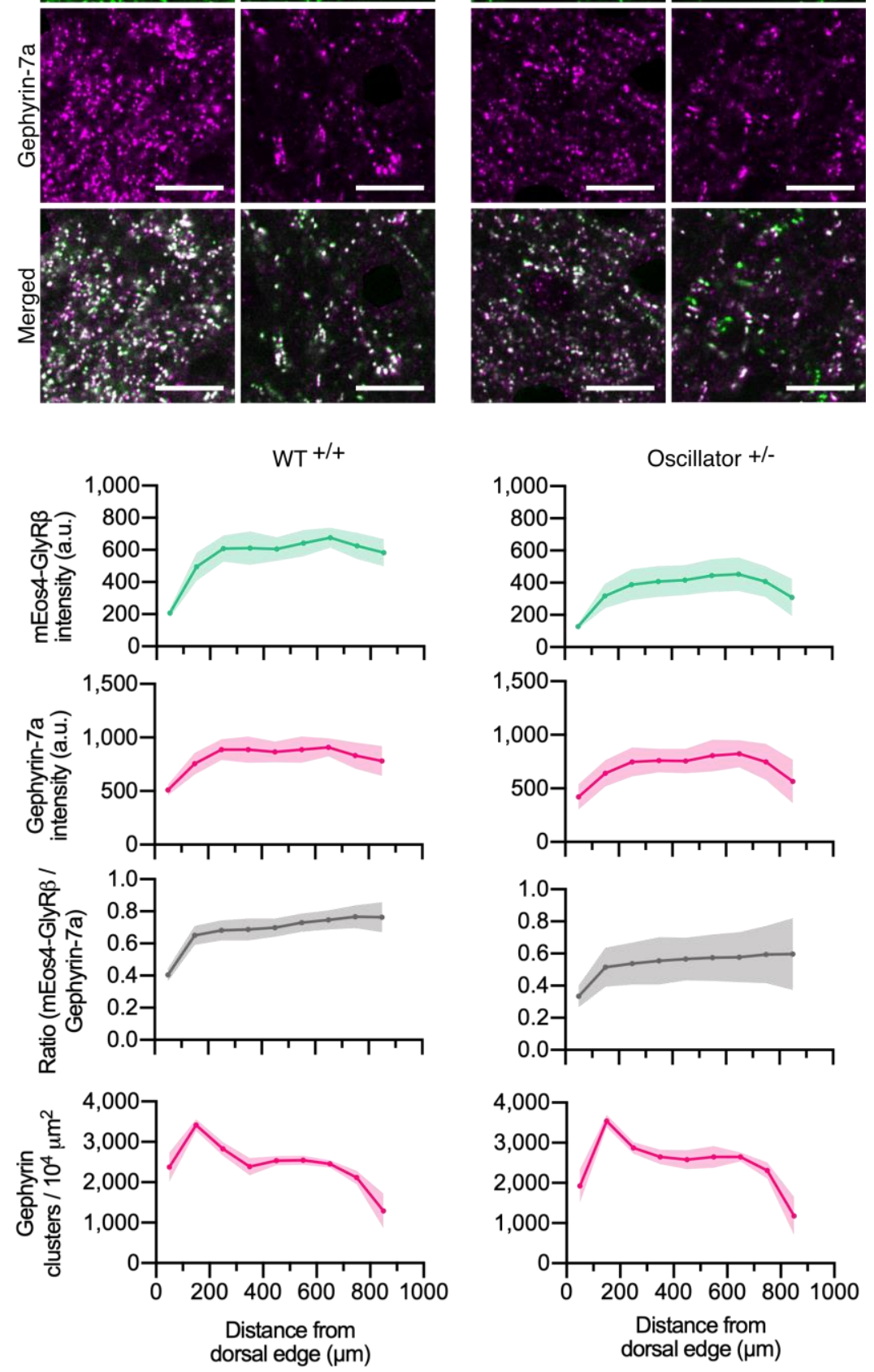

Fig. 4. Quantitative confocal imaging of endogenous GlyRs in the oscillator mouse

model. (A) Representative confocal images of dorsal and ventral synapses from heterozygous oscillator mice (+/-) compared to homozygous WT (+/+) littermates. All mice are homozygous for mEos $4 b-G l y R \beta$ (green), with gephyrin-7a immunolabeling (magenta). Scale bar $=10 \mu \mathrm{m}$. (B) Mean intensity $\pm 95 \%$ confidence interval of mEos $4 \mathrm{~b}-\mathrm{GlyR} \beta$ and gephyrin$7 \mathrm{a}$ at gephyrin-positive puncta, and numbers of gephyrin clusters measured from distal edge of spinal cord in 2 month old mice. $\mathrm{N}=9-11$ images from 9-11 tissue slices from 2 mice per

951 genotype. 

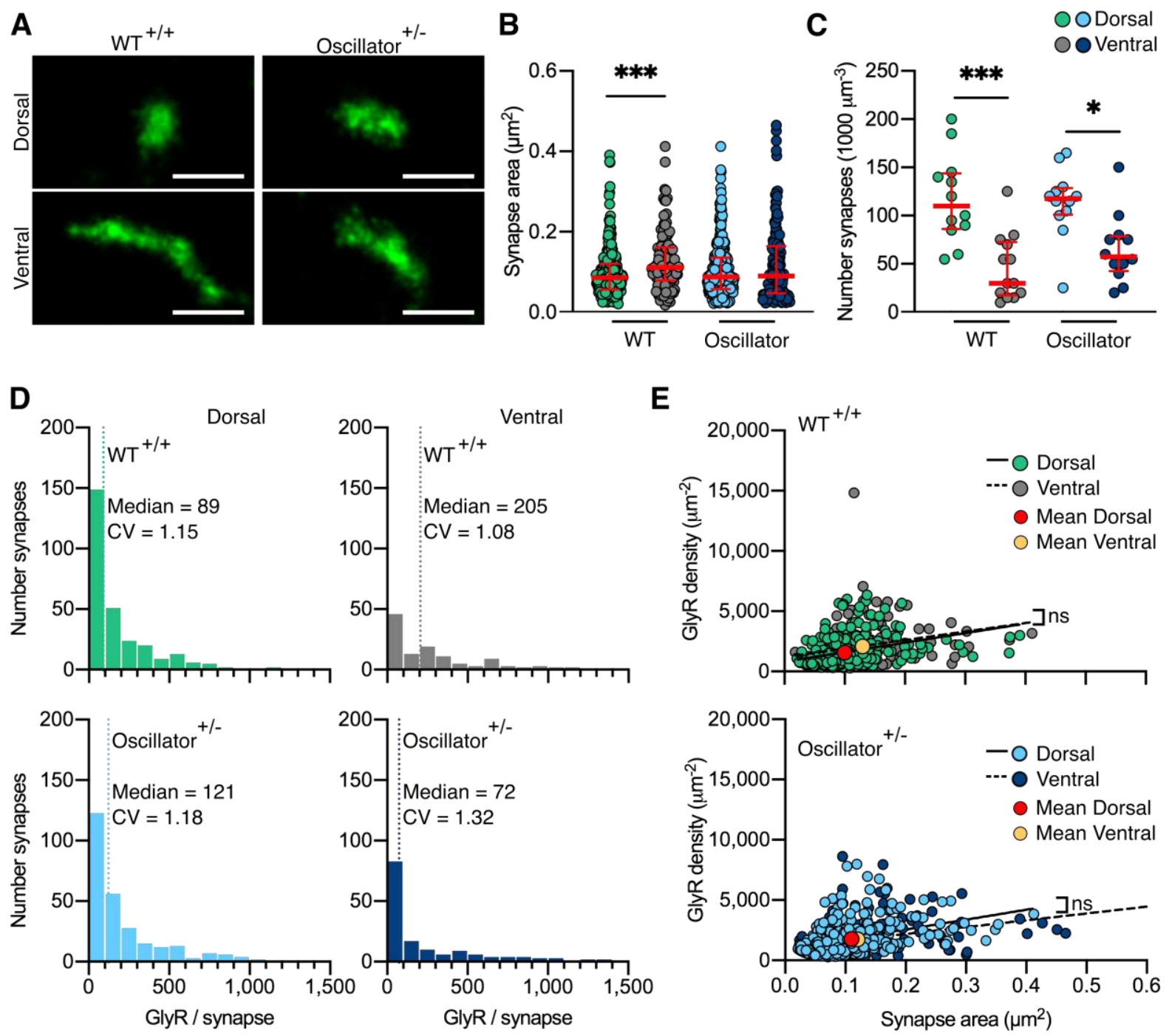

Fig. 5. PALM imaging of the GlyR in the oscillator mouse model. (A) Representative PALM reconstructions of $m E$ Es $4 \mathrm{~b}-\mathrm{GlyR} \beta$ at single dorsal and ventral synapses in heterozygous (+/-) oscillator and homozygous $(+/+)$ WT littermates. All mice are homozygous for mEos $4 \mathrm{~b}-\mathrm{GlyR} \beta$. Scale bar $=500 \mathrm{~nm}$. (B) Area of dorsal vs ventral synapses in heterozygous oscillator vs WT littermates. Plot shows median \pm interquartile range. $\mathrm{N}=$ 120-282 synapses from 24 images from 9-11 tissue slices from 2 mice per genotype. Nonparametric Kruskal Wallis ANOVA with Dunn's multiple comparison test. (C) Number of synapses in dorsal and ventral tissue in heterozygous oscillator vs WT mice. Plot shows median \pm interquartile range. $\mathrm{N}=12-13$ images from 2 mice per genotype. Parametric oneway ANOVA with Tukey's multiple comparison test. (D) Histogram of the number of GlyRs per synapse calculated from the molecular conversion of detections (see Fig. S7, S11 and $\mathrm{S} 12)$. $\mathrm{N}=282 \mathrm{WT}$ dorsal and 120 ventral synapses, 273 oscillator dorsal and 156 ventral synapses from 24 images from 9-11 tissue slices from 2 mice per genotype. $\mathrm{CV}=$ coefficient of variation. (E) Scatter plots of GlyR density vs synapse area show no difference between dorsal and ventral synapse densities in WT and oscillator. $\mathrm{N}=$ same as in (D). *p $<0.05$, 